\title{
EFFECTS OF DEPRESSION AND ANTIDEPRESSANT USE ON GOAL SETTING AND BARRIER IDENTIFICATION AMONG PATIENTS WITH TYPE 2 DIABETES
}

\author{
by \\ Hsiang-Yu Chen \\ B.S., Taipei Medical University, Taiwan, 2006
}

\author{
Submitted to the Graduate Faculty of \\ Department of Epidemiology \\ Graduate School of Public Health in partial fulfillment \\ of the requirements for the degree of \\ Master of Science
}

University of Pittsburgh 
UNIVERSITY OF PITTSBURGH

Graduate School of Public Health

This thesis was presented

by

\section{Hsiang-Yu Chen}

It was defended on

August 11, 2009

and approved by

Thesis Advisor:

Janice Zgibor, RPh, PhD

Assistant Professor

Department of Epidemiology

Graduate School of Public Health

University of Pittsburgh

Committee Member:

Denise Charron-Prochownik, PhD, RN, CPNP, FAAN

Professor

Department of Health Promotion and Development

School of Nursing

University of Pittsburgh

Committee Member:

Kristine Ruppert, DrPH

Biostatistician

University of Pittsburgh Diabetes Institute 
Copyright (c) by Hsiang-Yu Chen

2009 
Janice Zgibor, RPh, PhD

\title{
EFFECTS OF DEPRESSION AND ANTIDEPRESSANT USE ON GOAL SETTING AND BARRIER IDENTIFICATION AMONG PATIENTS WITH TYPE 2 DIABETES
}

\author{
Hsiang-Yu Chen, M.S.
}

University of Pittsburgh, 2009

Diabetes self-care plays a vital role in achieving better diabetes outcomes. To enhance diabetes self-care, the strategies of goal setting and barrier identification are widely used to assist people in making behavior change. Depression is a common co-morbidity and a barrier to self-care in people with diabetes. The purpose of this study was to examine the effects of depression and antidepressant use on goal setting and barrier identification in patients with type 2 diabetes.

In patients with type 2 diabetes enrolled in the American Association of Diabetes Educators (AADE) Outcomes System as part of their routine diabetes education, 778 patients were included into this analysis. Self-report depression, 7 self-identified behavior change goals, and 13 barriers to diabetes self-care were collected from the Diabetes Self-management Assessment Report Tool (D-SMART ${ }^{\circledR}$ ); antidepressant use was determined from the Diabetes Educator Tool (D-ET®). Multiple linear regression was used for the number of goals and the number of barriers with controls for relevant covariates.

Patients with and without depression had a similar number of self-identified behavior change goals $(\mathrm{P}=0.47)$, whereas patients with depression had 1.01 barriers to diabetes self-care greater than those without depression $(\mathrm{P}=0.0001)$. In the depressed subgroup, there was no 
significant difference between those with and without antidepressant use in the number of goals (model 3A, $\mathrm{P}=0.18$; model 3B, $\mathrm{P}=0.35$ ) and in the number of barriers $(\mathrm{P}=0.99)$.

Since depression was related to a greater number of barriers to self-care, depression screening is important in patients with diabetes. Although antidepressant use had no association with the number of goals or the number of barriers, antidepressants are still useful in treating depression in patients with diabetes. In addition, collaborative treatment should be integrated to provide maximal benefit to improve both diabetes and depression. These conclusions are of public health significance and can be used to develop behavior change strategies to improve diabetes self-care. 
TABLE OF CONTENTS

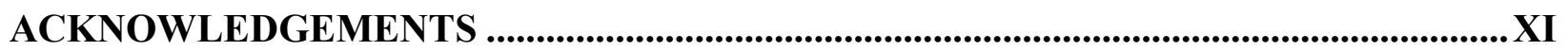

1.0 INTRODUCTION

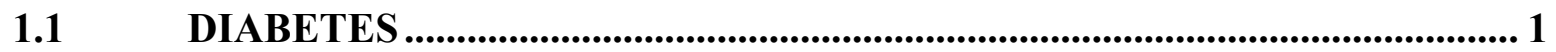

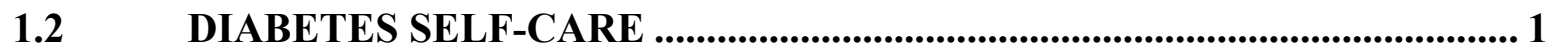

1.3 GOAL SETTING AND BARRIER IDENTIFICATION ................................ 2

1.4 DEPRESSION AND DIABETES

1.5 DEPRESSION TREATMENT AND DIABETES .............................................. 4

1.6 PURPOSE OF THE STUDY .........................................................................

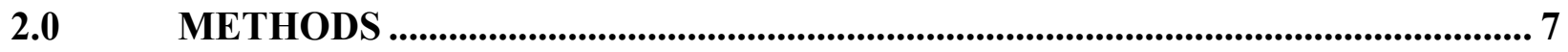

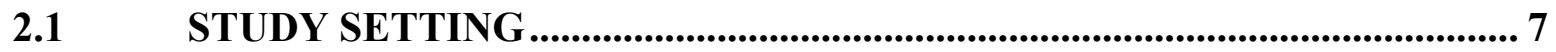

2.2 MEASUREMENT _................................................................................................ 8

$2.3 \quad$ STATISTICAL ANALYSIS _................................................................................ 9

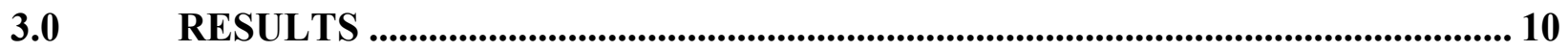

3.1 COMPARISONS B ETWEEN P ATIENTS I NCLUDED AND E XCLUDED 10

3.2 DEMOGRAPHIC AND CLINICAL CHARACTERISTICS ......................... 10

3.3 UNADJUSTED SELF-IDENTIFIED BEHAVIOR CHANGE GOALS AND

UNADJUSTED BARRIERS TO DIABETES SELF-CARE ............................................ 11 
I.4 LINEAR REGRESSION MODELS .................................................................. 12

4.0 DISCUSSION

S.1 SUMMARY OF FINDINGS ............................................................... 14

4.2 SIGNIFICANCE OF THE STUDY …................................................................. 14

4.3 POSSIBLE EXPLANATIONS ........................................................................ 15

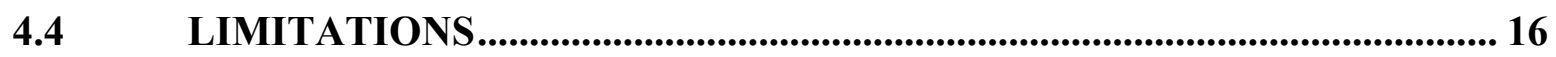

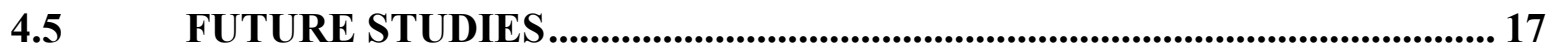

4.6 PUBLIC HEALTH SIGNIFICANCE......................................................... 18

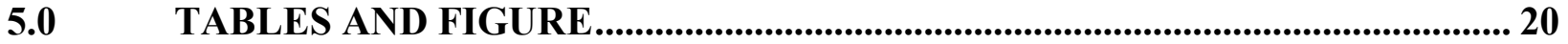

APPENDIX A : DEMOGRAPHIC AND CLINICAL CH ARACTERISTICS O F

PATIENTS IN STUDY AND OUT OF STUDY …......................................................... 45

APPENDIX B : ANTIDEPRESSANT ........................................................................................ 47

APPENDIX C : INSULIN ..................................................................................................... 48

BIBLIOGRAPHY 


\section{LIST OF TABLES}

Table 1: Characteristics of studies investigating goals in people with diabetes ........................ 20

Table 2: Major findings of studies investigating goals in people with diabetes........................ 23

Table 3: Characteristics of studies investigating barriers to self-care behaviors in people with

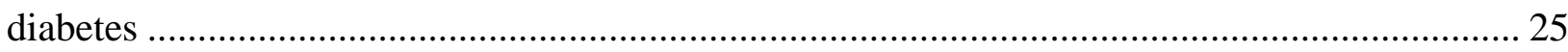

Table 4: Major findings of studies investigating barriers to self-care behaviors in people with

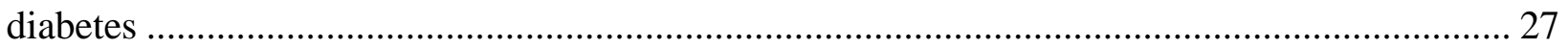

Table 5: Characteristics of studies investigating effects of depression on self-care behaviors in

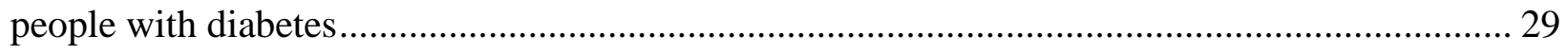

Table 6: Major findings of studies investigating effects of depression on self-care behaviors in

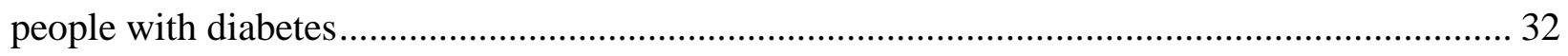

Table 7: Characteristics of studies investigating depression treatment in people with diabetes and

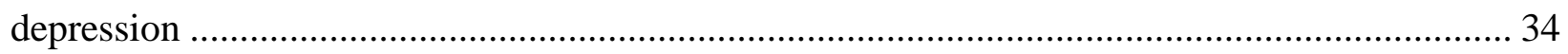

Table 8: Major findings of studies investigating depression treatment in people with diabetes and

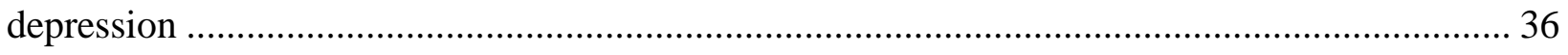

Table 9: Demographic and clinical characteristics of patients with type 2 diabetes by

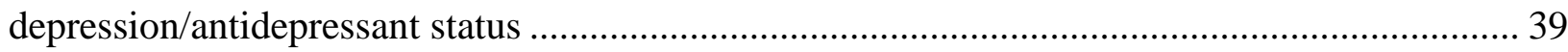


Table 10: Self-identified behavior change goals of patients with type 2 diabetes by

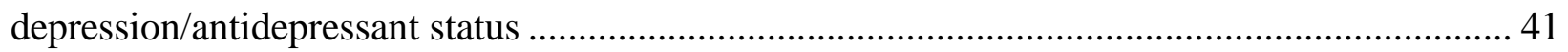

Table 11: Barriers to diabetes self-care of patients with type 2 diabetes by

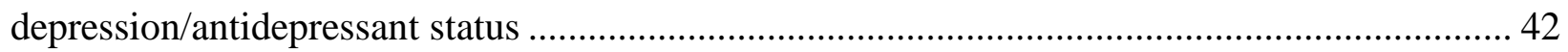

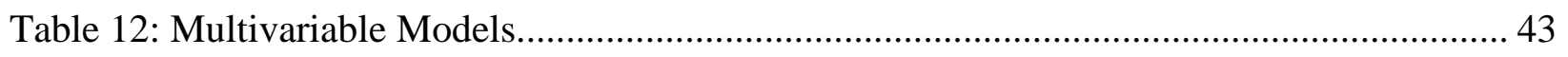




\section{LIST OF FIGURES}

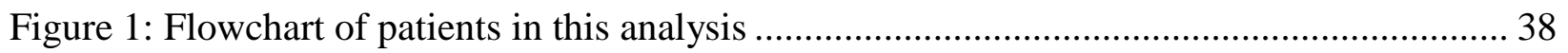




\section{ACKNOWLEDGEMENTS}

Two years ago, with excitement and nervousness, I left my home country and started my American life. To this point, I finished all the required courses, passed the comprehensive exam and the defense, and completed my master thesis. I would like to express my gratitude from the bottom of my heart to several people for their support and encouragement.

First, I would like to thank my advisor, Dr. Janice Zgibor, for giving me an abundance of guidance and support throughout these two years. She not only shared her intelligence and experience with me, but also encouraged me with her warm smile. I also appreciate all of the time and resources she extended to me along the way. From my perspective, she is the best advisor I have ever met.

I would like to thank Dr. Denise Charron-Prochownik for giving me helpful instruction to clarify the key behavior aspects of the study. I also appreciate her encouragement and suggestions during my thesis process.

I would like to thank Dr. Kristine Ruppert for her instruction in statistical analysis, especially in model building. I appreciate her intelligence to make a perfect connection between statistical classes and a real research.

I would like to thank Bill Noullet for his provision of the data and his help to solve any problem in the data, as well as his encouragement for my research. 
In addition, much gratitude is owed to my parents for their everlasting love and support from the very beginning. I would like to thank my boy friend, Jesse Yen-Chih Hsu, for his consideration and everything he has done for me. Last, but not the least, I would like to thank my family, friends, and classmates for all of their support throughout my tenure in the program. 


\subsection{INTRODUCTION}

\subsection{DIABETES}

Diabetes is the seventh leading cause of death reported on U.S. death certificates in 2006. ${ }^{1}$ The Centers for Disease Control and Prevention (CDC) estimates that 7.8\% of the U.S. population (nearly 23.6 million people) suffered from diabetes in 2007. ${ }^{1}$ While an estimated 17.9 million people are diagnosed with diabetes, 5.7 million people (nearly one quarter) are unaware that they have the disease. ${ }^{1}$

Diabetes is marked by high levels of blood glucose resulting from a shortage of insulin or a decreased ability to use insulin. Diabetes can lead to serious complications, such as cardiovascular disease, kidney disease, nerve damage, and blindness. People with diabetes also have higher premature mortality along with reduced life expectancy by 7-7.5 years. ${ }^{2}$ In order to prevent these complications, achieving adequate control of risk factors is important.

\subsection{DIABETES SELF-CARE}

Diabetes self-care behaviors play a vital role in achieving optimal glycemic control, retarding the progression of complications, and decreasing morbidity and mortality associated with diabetes. ${ }^{3-6}$ Defined by American Association of Diabetes Educators (AADE), self-care behaviors are 
healthy eating, being active, monitoring blood glucose, taking medication, problem solving, risk reduction activities, and healthy coping. There are known as AADE7 Self-Care Behaviors. ${ }^{7}$ A previous study ${ }^{8}$ showed that $95 \%$ of the routine daily care essential for maintaining glucose control needs to be provided by the diabetes patient, demonstrating the necessity for good diabetes self-care. According to a recent survey of US nurses and physicians ${ }^{9}$, promotion of effective self-care behaviors is also regarded as one of five key goals that need to be accomplished to improve diabetes outcomes.

\subsection{GOAL SETTING AND BARRIER IDENTIFICATION}

To improve diabetes self-care behaviors, the strategies of goal setting and barrier identification are widely used to assist people in making behavior change. ${ }^{10-12}$ Goal setting is a collaborative process in which the patient is an active participant in deciding their own diabetes regimens. ${ }^{11}$ This method may help people to improve recall of daily demands of diabetes and motivate them to participate in diabetes self-care. People with diabetes usually identify diabetes self-care goals as linked to their life goals, such as longevity, spending time with family, and maintaining independence. ${ }^{13,14}$ Factors influencing diabetes self-care goals include health care providers, family, and ancillary and outside resources. ${ }^{13,} 14$ In addition, Estabrooks et al. ${ }^{15}$ found that diabetes patients who were involved in selecting goals for diabetes self-care often selected the goals for which they needed to make the most change. For instance, those selecting a goal to increase physical activity were significantly less active at baseline than those choosing a goal to

decrease fat consumption or to increase fruit and vegetable consumption. ${ }^{15}$ People who 
participate in the goal-setting process are more likely to overcome potential barriers to self-care and to achieve favorable diabetes outcomes. ${ }^{11,14-18}$ (See Table 1 and Table 2)

Barrier identification also minimizes adverse effects on adherence to self-care behaviors. ${ }^{19}$ Most diabetes patients encounter barriers to self-care and these barriers are a major challenge when they deal with daily demands of diabetes. ${ }^{20-22}$ The most frequently reported barriers to diabetes self-care include cost, time constraints, inconvenience, low self-efficacy, limited coping skills and knowledge, reduced quality-of-life, complications and functional disabilities, inadequate resources, limited social and family support, complex regimen, poor patient-provider relationship, invasive characteristic for glucose monitoring, and depression or distress. ${ }^{13,23-28}$ Diabetes patients with multiple barriers are also likely to reduce adherence to diabetes self-care. ${ }^{26,29}$ (See Table 3 and Table 4)

\subsection{DEPRESSION AND DIABETES}

Depression is a common co-morbidity and a barrier to diabetes self-care in people with diabetes mellitus. ${ }^{30}$ The risk of depression is $50-100 \%$ higher in people with diabetes compared to the general population. ${ }^{31}$ People with diabetes not only need to continuously pay attention to their complex regimens, but also have the fear of hypoglycemia and diabetes complications. These reasons can increase perceived stress, leading to high rates of depression. ${ }^{32}$ In addition, because of loss of energy and motivation, negative cognition, pessimistic attributional style, and passive coping strategies, ${ }^{33}$ people with depression are less likely than those without depression to optimally manage their diabetes. 
For people with diabetes, depression is associated with poor glycemic control, leading to more complications, ${ }^{34}$ higher mortality rates, ${ }^{35}$ and greater health care costs. ${ }^{36}$ Depression is also related to poor adherence to diabetes self-care. Most studies show that diabetes patients with depression are more likely than those without depression to have an unhealthy diet ${ }^{37-41}$ and low medication adherence, ${ }^{37,39-43}$ while those with and without depression are similar in compliance with glucose monitoring ${ }^{37-41}$ and with foot care. ${ }^{39,41}$ There are inconsistent findings regarding the association between depression and exercise. ${ }^{37-41}$ To clarify the relationships between depression, poor diabetes self-care, and adverse diabetes outcomes, McKellar et al. ${ }^{44}$ used structural equation models to find that depression increased symptoms of poor glucose control through lowering adherence to diabetes self-care. Accordingly, if these people receive appropriate depression treatment, they may improve diabetes outcomes by increasing adherence to diabetes self-care. (See Table 5 and Table 6)

\subsection{DEPRESSION TREATMENT AND DIABETES}

Several randomized controlled trials evaluated the effects of depression treatment (antidepressants, behavior therapies, or both) in people with diabetes and depression. ${ }^{45-50}$ Most studies found a significant improvement in depression for those receiving antidepressants and/or behavior therapies, while effects of depression treatment on glycemic control have been mixed. ${ }^{45}$, ${ }^{47-50}$ In addition to effects on depression and glycemic control, four studies ${ }^{46,48-50}$ investigated the association between enhanced depression treatment (antidepressants, behavior therapies, or both) and diabetes self-care. Among those with type 2 diabetes and major depression, people receiving cognitive behavior therapy plus diabetes education had reduced adherence to self-monitoring of 
blood glucose compared to those receiving diabetes education alone during the 10-week treatment period. ${ }^{49}$ In a study of older people with diabetes and depression, the intervention (including antidepressants and behavior therapies) increased people's physical activity but had no effects on other self-care behaviors (diet, diabetes medication, glucose monitoring, and foot inspection) relative to usual care during the 12 -month intervention period. ${ }^{50}$ In another 12 -month trial comparing collaborative depression treatment (antidepressants and/or behavior therapies) with usual care among people with diabetes and depression, the two groups reported no difference in diabetes self-care (diet, exercise, smoking, and medication adherence to lipidlowering and antihypertensive medicines) except a higher rate of non-adherence to oral hypoglycemic agents in intervention group. ${ }^{46} \mathrm{~A}$ trial comparing nortriptyline with placebo in people with poorly controlled diabetes also showed no effects on compliance with glucose monitoring and with medication regimen over the 8-week treatment period. ${ }^{48}$ From these studies, the relationship between treatment of depression and diabetes self-care seems to be inconsistent, and only one study ${ }^{48}$ specifically investigated the effects of antidepressant on diabetes self-care. (See Table 7 and Table 8)

\subsection{PURPOSE OF THE STUDY}

Diabetes self-care is not a small task from a patient's perspective. Depression increases difficulties in achieving good diabetes self-care. Although a number of studies ${ }^{37-43}$ investigated the association between depression and diabetes self-care behaviors, there is no literature addressing the effects of depression on goal setting and barrier identification in people with diabetes. There is only one study to the best of our knowledge examining the effects of 
depression on goal achievement for control of glucose, lipids, and blood pressure, ${ }^{51}$ rather than on goal setting for adherence to diabetes self-care behaviors. Moreover, whether goal setting and barrier identification are improved by alleviated depression due to antidepressant use is still unanswered. Therefore, our first study aim is to evaluate the effects of depression on the number of self-identified behavior change goals and the number of barriers to diabetes self-care among patients with type 2 diabetes. Our second aim is to study the treatment effects of antidepressants on the number of self-identified behavior change goals and the number of barriers to diabetes self-care in the depressed subgroup. 


\subsection{METHODS}

\subsection{STUDY SETTING}

This analysis was conducted using data from AADE Outcomes System, which was developed to facilitate the delivery, documentation, and evaluation of patient behavior change in the provision of diabetes self-management education (DSME). ${ }^{7}$ The AADE Outcomes System was integrated into Internet, touch-screen, and telephonic systems within 8 sites in the Pittsburgh Regional Initiative for Diabetes Education (PRIDE) network. ${ }^{10}$ PRIDE is a regional health care collaboration established by the University of Pittsburgh Diabetes Institute to improve diabetes education and care in western Pennsylvania. ${ }^{52}$ Patients with type 1 or type 2 diabetes were enrolled in the system as part of their routine diabetes education visits from 2005 to 2008. To be eligible for this study, complete data in the following fields were needed: self-report depression, antidepressant use, self-identified behavior change goals, and barriers to diabetes self-care. Also, only patients with type 2 diabetes were included. Therefore, final sample size was 778 (Figure 1). This study was approved by the Institutional Review Boards of the University of Pittsburgh. 


\subsection{MEASUREMENT}

Two instruments were developed to collect data from patients (the Diabetes Self-management Assessment Report Tool, D-SMART ${ }^{\circledR}$ ) and from diabetes educators (the Diabetes Educator Tool, D-ET $\left.{ }^{\circledR}\right){ }^{10}$ The D-SMART is a self-report instrument that gathers information about (1) demographics and health history and (2) behaviors and behavior change goals, organized in terms of the domains of the AADE7 Self-Care Behaviors. ${ }^{10}$ Patients were asked to complete a baseline D-SMART prior to the start of DSME program. The D-ET was completed by the diabetes educator during the provision of DSME, and provided an opportunity for the educator to record medical information about the patient and the educator's assessment of the patient's needs and progress. In the present study, self-report depression, 7 self-identified behavior change goals, and 13 barriers to self-care were collected from the D-SMART®; antidepressant use was determined from the D-ET®. Demographic (age, gender, race, education status, smoking, alcohol drinking, family history of diabetes, diabetes duration, and diabetes education) and clinical (BMI, HbA1c, complications, and insulin use) data were obtained from either the DSMART or the D-ET.

Depression status was identified if patients reported "Depression or anxiety" in D-

SMART or had records of antidepressant use in D-ET. ${ }^{41}$ To determine self-identified behavior change goals, patients chose the domains in which they would like to make changes including activity, eating, medication taking, monitoring, problem solving for blood sugars and sick days, reducing risks of diabetes complications, and living with diabetes. Patients also identified the level of each barrier that kept them from making the change. Among the four levels of each barrier to self-care, patients answering "A lot ", "some”, "a little” were categorized as those who had barriers; patients answering "Not at all" were categorized as those who did not have barriers. 


\subsection{STATISTICAL ANALYSIS}

Demographic and clinical data were reported using measures of central tendency (percentage or mean/medium). Comparisons between patients with and without depression or with and without antidepressant use were performed using the $\chi^{2}$ test for categorical variables. Continuous variables were analyzed using the Student t or Wilcoxon rank sum test.

Multiple linear regression was employed for the number of self-identified behavior change goals and the number of barriers to self-care. Univariate modeling was performed followed by multivariable modeling. Those covariates whose p-values were $<0.10$ were considered for multivariable models. Covariates for consideration included: depression status $(\mathrm{Y} / \mathrm{N})$, antidepressant use $(\mathrm{Y} / \mathrm{N})$, age (continuous), gender, race (white/black/others), education status (did not finish high school/high school/some college or greater), BMI (continuous), smoking (never/former/current), alcohol drinking ( $\mathrm{Y} / \mathrm{N})$, family history of diabetes $(\mathrm{Y} / \mathrm{N})$, diabetes duration (continuous), diabetes education $(\mathrm{Y} / \mathrm{N})$, the number of diabetes complications (continuous), HbA1c level (continuous), insulin use (Y/N), and the number of barriers (7-13/06). Transformation of covariates was performed where necessary. P-values $<0.05$ were considered significant. All analysis was completed using SAS 9.2. (SAS Institute Inc., Cary, North Carolina) 


\subsection{RESULTS}

\subsection{COMPARISONS BETWEEN PATIENTS INCLUDED AND EXCLUDED}

Upon examination of those excluded from this analysis, we found that patients included were more likely to be white people with higher BMI, less alcohol drinking, family history of diabetes, insulin prescriptions, longer duration of diabetes, and more diabetes complications. There was no significant difference between patients included and excluded in depression status, age, gender, education status, smoking, diabetes education, and HbA1c level. (See Appendix A)

\subsection{DEMOGRAPHIC AND CLINICAL CHARACTERISTICS}

Demographic and clinical characteristics of patients by depression/antidepressant status (ie. nondepressed patients, depressed patients with antidepressant, and depressed patients without antidepressant) are shown in Table 9. Between patients with and without depression, depressed patients were more likely to be younger (56 vs. $60 \mathrm{yr}$ ), obese (34.38 vs. $33.16 \mathrm{~kg} / \mathrm{m}^{2}$ ), female (71.96\% vs. $55.03 \%$ ), currently smoking (28.51\% vs. $18.25 \%$ ), to have more diabetes complications, and to suffer from kidney or bladder problems, numbness or pain, and vision problems, while they were less likely to drink alcohol (20.37\% vs. 26.64\%). Race, education status, family history of diabetes, duration of diabetes, diabetes education, HbA1c level, insulin 
use, and the prevalence of some complications (such as high blood pressure, stroke, heart disease or chest pain, and problems with sexual function) were similar in patients with and without depression. Between patients with and without antidepressant use in the depressed subgroup, they were similar in most demographic and clinical characteristics except that those with antidepressant use were younger (55 vs. 57 yr) and were more likely to have diabetes education (29.44\% vs. $14.44 \%$ ) than those without antidepressant use.

\subsection{UNADJUSTED SELF-IDENTIFIED BEHAVIOR CHANGE GOALS AND UNADJUSTED BARRIERS TO DIABETES SELF-CARE}

By depression/antidepressant status, unadjusted self-identified behavior change goals and unadjusted barriers to diabetes self-care are presented in Table 10 and Table 11, respectively. Patients with and without depression were similar in the number of self-identified behavior change goals $(\mathrm{P}=0.11)$. In the depressed subgroup, patients with and without antidepressant use were also similar in the number of goals $(\mathrm{P}=0.26)$. For barriers to diabetes self-care, patients with depression had a greater number of barriers to self-care compared to those without depression (7 vs. 6, $\mathrm{P}<.0001$ ), whereas in the depressed subgroup, patients with and without antidepressant use were similar in the number of barriers $(\mathrm{P}=0.75)$. 


\subsection{LINEAR REGRESSION MODELS}

Multiple linear regression was used to evaluate the effects of depression or antidepressant use on the number of goals or the number of barriers with controls for relevant covariates (Table 12). From the model 1, depression had no association with the number of goals after adjusting for age, race, education, and the number of barriers $(\mathrm{P}=0.47)$. Patients who were young $(\mathrm{P}<.0001)$, white (black, $\mathrm{P}=0.02$; others, $\mathrm{P}=0.01$ ), educated (did not finish high school, $\mathrm{P}<.0001$; high school diploma, $\mathrm{P}=0.0002)$, and had a greater number of barriers $(\mathrm{P}=0.03)$ were more likely to have a greater number of goals. From the model 2, patients with depression had 1.01 barriers greater than those without depression after controlling for BMI, race, education, age, and insulin prescription $(\mathrm{P}=0.0001)$. Patients with a greater number of barriers were more likely to have higher BMI $(\mathrm{P}<.0001)$, to be black or other race (black, $\mathrm{P}=0.05$; others, $\mathrm{P}=0.006$ ), to have lower education (did not finish high school, $\mathrm{P}=0.01$; high school diploma, $\mathrm{P}=0.11$ ), and to have insulin prescription $(\mathrm{P}<.0001)$. From the model 3A, there was no relation between antidepressant use and the number of goals in the depressed subgroup after adjusting for age, race, education, insulin prescription, and family history of diabetes $(\mathrm{P}=0.18)$. In the depressed subgroup, patients who were white people (black, $\mathrm{P}=0.04$; others, $\mathrm{P}=0.001$ ), had higher education (did not finish high school, $\mathrm{P}=0.05$; high school diploma, $\mathrm{P}=0.13$ ), did not use insulin $(P=0.07)$, and had family history of diabetes $(P=0.06)$ were more likely to have a greater number of goals. After excluding those covariates with borderline $\mathrm{P}$ value (such as education, insulin use, and family history of diabetes) (the model 3B), antidepressant use was still not significantly related to the number of goals after adjusting for age and race $(\mathrm{P}=0.35)$. According to this model, white people (black, $\mathrm{P}=0.05$; others, $\mathrm{P}=0.003$ ) with younger age $(\mathrm{P}=$ 0.02) were more likely to have a greater number of goals in the depressed subgroup. From the 
model 4, we found that depressed patients with and without antidepressants were similar in the number of barriers after controlling for age, BMI, education, and insulin use $(\mathrm{P}=0.99)$. Patients with a greater number of barriers were more likely to have higher BMI $(P=0.0003)$, to have lower education (did not finish high school, $\mathrm{P}=0.04$; high school diploma, $\mathrm{P}=0.24$ ), and to use insulin $(\mathrm{P}=0.004)$. The main findings remained the same even though additionally including HbA1c level, insulin use, or both as covariates in each model. 


\subsection{DISCUSSION}

\subsection{SUMMARY OF FINDINGS}

In patients with type 2 diabetes enrolled in the AADE Outcomes System as part of their routine diabetes education, those with and without depression had a similar number of self-identified behavior change goals, whereas patients with depression had 1.01 barriers to diabetes self-care greater than those without depression. In the depressed subgroup, antidepressant use had no association with the number of goals they set and the number of barriers they identified.

\subsection{SIGNIFICANCE OF THE STUDY}

Goal setting and barrier identification play important roles in helping patients make behavior change and achieve better diabetes self-care ultimately. Depression is not only a common comorbidity in patients with diabetes, but also a well-known barrier that affects diabetes self-care. Although several studies show negative effects of depression on diabetes self-care ${ }^{37-43}$, whether depression has influences on goal setting and barrier identification has not been well-studied. The available study investigated the effects of depression on goal achievement for clinical outcomes, $^{51}$ rather than on goal setting for diabetes self-care. A number of studies explored barriers in patients with diabetes, ${ }^{13,25-28}$ rather than evaluated the effects of depression on 
patients' barriers to diabetes self-care. Thus, our study is unique and provides important information for diabetes educators to help patients with diabetes and depression.

\subsection{POSSIBLE EXPLANATIONS}

Beyond our expectation that patients with depression have decreased interest in making behavior change due to associated characteristics (such as pessimism and fatigue), we found that there was no association between depression and the number of self-identified behavior change goals. One possible explanation is that the patient in our study was those who received routine diabetes education, and therefore these patients were more active to pursue intensive treatments to achieve better diabetes outcomes. This impetus to seek help to improve their disease may compromise their negative behavioral style, leading to the absence of an effect of depression on their goal setting.

Our study showed that patients with depression had a greater number of barriers to diabetes self-care than those without depression. However, there was no difference between those with and without antidepressant use in the depressed subgroup. This result is similar to previous findings that the treatment of depression (antidepressants and/or behavior therapies) had no effects on diabetes self-care behaviors (specifically, nutritional recommendations, smoking

cessation, and foot care). ${ }^{46,48-50}$ Thus, these findings suggest that the treatment of depression alone may be not enough to address patients' barriers for them to achieve better diabetes selfcare. Overcoming patients' barriers to diabetes self-care may require intensive interventions specific to each barrier. Another possibility is that complex diabetes regimens may reduce 
patients' adherence to antidepressants ${ }^{46,50}$, leading to equal performance between patients with and without antidepressants.

\subsection{LIMITATIONS}

Our study has some limitations that warrant consideration. First, this study is cross-sectional, and therefore the temporal association cannot be established. For instance, we cannot determine whether depression increases the number of barriers to diabetes self-care, or a greater number of barriers to diabetes self-care make patients feel depressed, or both. Thus, future longitudinal studies are needed to examine all the cause-effect relationships in this study. Second, the goal setting and barrier identification were determined by patients in the D-SMART. Since there were 7 domains in goal setting and 13 items in barrier identification, some patients may feel burdened by completing all the questions and may not answer all questions for goal setting and barrier identification. Thus, among 1575 patients with type 2 diabetes in this system, 442 (28.06\%) patients had missing data in goal setting and 428 (27.17\%) patients in barrier identification. Furthermore, those who were excluded from this study due to missing values were different from those who were included in some demographic and clinical characteristics (such as race, BMI, alcohol drinking, family history of diabetes, insulin use, diabetes duration, and complications), which may restrict the generalizability of the results. Third, to identify those with depression, we relied on patients' self-report in D-SMART and their records of antidepressant use in D-ET. Since some patients may not reveal their depression tendency and not all depressed patients need to take antidepressants, the identification of depression on the basis of self-report and antidepressant use may underestimate the number of patients with depression. This 
misclassification bias may account for inability to detect significant differences. To avoid this bias, structured interviews are preferred in future studies to make a diagnosis of major depression. In addition, formal psychiatric assessment is considered to be the gold standard in identifying depressed patients. Forth, the record of antidepressant use was obtained from the diabetes educator during the provision of DSME. However, the medication data indicated only medicines the patient prescribed, not medicines they actually took. Thus, the objective measurement (e.g., electronic monitoring caps ${ }^{43}$ ) is needed to monitor medication adherence in future studies. Fifth, some antidepressants are not only used to treat depression, but also taken to relieve other disorders. For example, duloxetine, a selective serotonin and norepinephrine reuptake inhibitor, is not only regarded as an antidepressant, but also wildly used to inhibit pain due to diabetic peripheral neuropathy. In our study, only 13 (2\%) patients had records of duloxetine, and therefore this was not likely to affect our results.

\subsection{FUTURE STUDIES}

Based on our findings, patients with depression had about one barrier greater than those without depression. Although this difference between those with and without depression in the number of barriers is small, whether it may bring about significant influences on diabetes self-care is unanswered. It is possible that depressed patients are likely to have a certain item of barriers to diabetes self-care, and therefore they are likely to have poor adherence to the related domains of diabetes self-care. Thus, in future studies, it is necessary to examine the effects of depression on each item of barriers and also to evaluate the clinical significance of these effects on diabetes self-care. 
Goal setting, skill acquisition, and maintenance of motivation are important components for diabetes patients to achieve successful self-care. ${ }^{53,54}$ It is well-known that depression is related to poor diabetes self-care. ${ }^{37-43}$ In our study, we found that patients with and without depression had a similar number of self-identified behavior change goals. To confirm that patients with and without depression are similar in goal setting, investigating the effects of depression on identifying each domain of behavior change goals is needed. If patients with and without depression do perform similarly in goal setting, it suggests that depressed patients may have some problems to acquire coping skill or to maintain motivation so that they are less likely to have better diabetes self-care. Thus, exploring the factors that affect depressed patients in coping skill and maintenance of motivation is important in future studies.

\subsection{PUBLIC HEALTH SIGNIFICANCE}

Since depression was related to an increased number of barriers to diabetes self-care, depression screening is important in patients with diabetes. If depressed patients can be identified in the early stages, intensive interventions can be applied earlier to help them overcome potential barriers and then achieve better diabetes self-care. Although antidepressant use had no association with the number of goals or the number of barriers, it does not indicate that antidepressants are not useful in patients with diabetes and depression. Antidepressant use is still important in treating depression for patients with diabetes and depression. ${ }^{48}$ Additionally, effective diabetes treatment may be compromised by depression-related characteristics (e.g., hopeless), while effective depression treatment may be diminished by diabetes complications (e.g., pain). Thus, collaborative treatment should be integrated to provide maximal benefit to 
improve both diabetes and depression, and also to avoid adverse influences of one disease resulted from the treatment of the other disease. 


\subsection{TABLES AND FIGURE}

Table 1: Characteristics of studies investigating goals in people with diabetes

\begin{tabular}{|c|c|c|c|c|c|}
\hline AUTHOR & $\begin{array}{c}\text { STUDY } \\
\text { DESIGN }\end{array}$ & STUDY AIM & POPULATION & $\begin{array}{l}\text { SAMPLE } \\
\text { SIZE }\end{array}$ & METHODS/MEASUREMENTS \\
\hline $\begin{array}{l}\text { Rush WA et } \\
\text { al. }(2008)^{51}\end{array}$ & $\begin{array}{l}\text { Prospective } \\
\text { cohort study }\end{array}$ & $\begin{array}{l}\text { To examine whether depressive } \\
\text { symptoms are associated with } \\
\text { achievement of recommended goals } \\
\text { for control of glucose, lipids, and } \\
\text { blood pressure among patients with } \\
\text { diabetes. }\end{array}$ & $\begin{array}{l}\text { Inclusion: type } 1 \text { or type } 2 \\
\text { diabetes, and } \geq 18 \text { y/o } \\
\text { Exclusion: those without } \\
\text { pharmacy coverage }\end{array}$ & $\begin{array}{l}1223 \\
\text { subjects }\end{array}$ & $\begin{array}{l}\text { Depression } \\
\text { - Survey at baseline } \\
\text { - Self-reported } \\
\text { - } 2 \text { questions from the PHQ-2 screening tool } \\
\text { Goals for HbA1c }(\leq 7.0) \text {, LDL }(\leq 100) \text {, SBP }(\leq 130) \text {, } \\
\text { and DBP }(\leq 80) \\
\text { - Medical record } \\
\text { - } 1 \text {-year period after the survey }\end{array}$ \\
\hline $\begin{array}{l}\text { Morrow AS et } \\
\text { al. }(2008)^{13}\end{array}$ & $\begin{array}{l}\text { Cross- } \\
\text { sectional study }\end{array}$ & $\begin{array}{l}\text { To investigate the life and health } \\
\text { goals of older adults with diabetes, } \\
\text { and explore the factors that influence } \\
\text { their diabetes self-management. }\end{array}$ & $\begin{array}{l}\text { Inclusion: type } 2 \text { diabetes, } \geq \\
55 \mathrm{y} / \mathrm{o}, \text { hypertension, and at } \\
\text { least one other chronic } \\
\text { comorbidity }\end{array}$ & 24 subjects & $\begin{array}{l}\text { Qualitative in-depth interviews } \\
\text { - Prior to the interview, information about the } \\
\text { patient's medical history, ability to perform } \\
\text { activities of daily living, and demographic } \\
\text { characteristics was collected using questionnaires } \\
\text { administered by investigators. } \\
\text { - Health care goals, effects of diabetes and other } \\
\text { chronic conditions on daily life, self-management } \\
\text { practices, and communication with health care } \\
\text { providers were asked using interview guide. }\end{array}$ \\
\hline $\begin{array}{l}\text { Ismail K et al. } \\
(2008)^{55}\end{array}$ & $\begin{array}{l}\text { Randomized } \\
\text { controlled trial }\end{array}$ & $\begin{array}{l}\text { To determine whether motivational } \\
\text { enhancement therapy with or without } \\
\text { cognitive behavior therapy improves } \\
\text { glycemic control in type } 1 \text { diabetes } \\
\text { compared with usual care. }\end{array}$ & $\begin{array}{l}\text { Inclusion: type } 1 \text { diabetes for } \geq \\
2 \text { years, with HbA1c levels of } \\
8.2 \% \sim 15 \% \text {, and without } \\
\text { complications or severe } \\
\text { comorbid disease. }\end{array}$ & 344 subjects & $\begin{array}{l}\text { HbA1c (primary outcome) } \\
\text { Depression (secondary outcomes) } \\
\text { - Self-report } \\
\text { - Patient Health Questionnaire-9 (score range, } 0 \text { to } \\
\text { 27; scores } \geq 10 \text { represent major depressive } \\
\text { disorder) } \\
\text { Diet, exercise, and blood sugar testing (secondary }\end{array}$ \\
\hline
\end{tabular}


Table 1: Characteristics of studies investigating goals in people with diabetes (cont.)

\begin{tabular}{|c|c|c|c|c|c|}
\hline & & & & & $\begin{array}{l}\text { outcomes) } \\
\text { • Revised Summary of Diabetes Self-Care } \\
\text { • Days in the last } 7 \text { days the participant engaged in } \\
\text { self-care (score range, } 0 \text { to } 7 \text { days) } \\
\text { Hypoglycemia (secondary outcomes) } \\
\text { • Hypoglycemia Fear Survey } \\
\text { - } 10 \text { behavior items (score range, } 0 \text { to } 40 \text { ) and } 13 \\
\text { worry items (score range, } 0 \text { to 52) self-rated on 5- } \\
\text { point Likert scales. } \\
\text { Quality of life (secondary outcomes) } \\
\text { - Satisfaction and impact subscales of the Diabetes } \\
\text { - Quality of Life scale (score range per subscale, } 1 \\
\text { to 5) } \\
\text { Body mass index (secondary outcomes) }\end{array}$ \\
\hline $\begin{array}{l}\text { Estabrooks } \\
\text { PA et al. } \\
(2005)^{15}\end{array}$ & $\begin{array}{l}\text { Randomized } \\
\text { controlled trial }\end{array}$ & $\begin{array}{l}\text { To determine the frequency and } \\
\text { effectiveness of behavioral goal } \\
\text { choices in the self-management of } \\
\text { diabetes and to test goal-setting } \\
\text { theory hypotheses that self-selection } \\
\text { and behavioral specificity of goals } \\
\text { are key to enhancing persistence. }\end{array}$ & $\begin{array}{l}\text { Inclusion: type } 2 \text { diabetes, and } \\
\geq 25 \mathrm{y} / \mathrm{o}\end{array}$ & 422 subjects & $\begin{array}{l}\text { Physical activity } \\
\text { - 11-item Behavioral Risk Factor Surveillance } \\
\text { System (BRFSS) } \\
\text { - A brief screener on frequency and duration of } \\
\text { vigorous and moderate-level activities } \\
\text { Dietary fat } \\
\text { - } 17 \text {-item Block Dietary Data Systems (BDDS) } \\
\text { - A brief calculation of the participant’s dietary fat } \\
\text { Fruits and vegetables intake } \\
\text { - 7-item BDDS “Fruit/Vegetable Screener” } \\
\text { - A brief scanner on current number of fruit and } \\
\text { vegetable portions consumed each day }\end{array}$ \\
\hline $\begin{array}{l}\text { Huang ES et } \\
\text { al. }(2005)^{14}\end{array}$ & $\begin{array}{l}\text { Qualitative } \\
\text { study }\end{array}$ & $\begin{array}{l}\text { To examine how older patients define } \\
\text { their healthcare goals, what factors } \\
\text { shape their goals, and the extent to } \\
\text { which their goals relate to self-care } \\
\text { behavior. }\end{array}$ & $\begin{array}{l}\text { Inclusion: type } 2 \text { diabetes, and } \\
\geq 65 \mathrm{y} / \mathrm{o}\end{array}$ & 28 subjects & $\begin{array}{l}\text { Semi-structured interviews } \\
\text { - The questions of the interview guide were } \\
\text { designed to explore patients' healthcare goals, } \\
\text { diabetes mellitus care goals, experiences with } \\
\text { diabetes mellitus, priorities for self-care strategies, } \\
\text { and daily self-care tasks }\end{array}$ \\
\hline $\begin{array}{l}\text { Rachmani } R \\
\text { et al. }(2005)^{17}\end{array}$ & $\begin{array}{l}\text { Randomized } \\
\text { controlled trial }\end{array}$ & $\begin{array}{l}\text { To examine whether motivating } \\
\text { patients to gain expertise and closely } \\
\text { following their risk parameters will } \\
\text { attenuate the course of microvascular } \\
\text { and cardiovascular sequelae of } \\
\text { diabetes. }\end{array}$ & $\begin{array}{l}\text { Inclusion: type } 2 \text { diabetes }<10 \\
\mathrm{yr}, 40-70 \mathrm{y} / \mathrm{o}, \mathrm{BMI} \leq 35 \\
\mathrm{~kg} / \mathrm{m}^{2}, \mathrm{BP} \geq 140 / 90 \mathrm{mmHg} \\
\mathrm{LDL} \geq 120 \mathrm{mg} / \mathrm{dl}, \text { serum } \\
\text { creatinine } \leq 2 \mathrm{mg} / \mathrm{dl}(176 \\
\mu \mathrm{mol} / \mathrm{L}), \text { albumin/creatinine } \\
\text { ratio }<200 \mathrm{mg} / \mathrm{g} ; \text { and no } \\
\text { history of myocardial } \\
\text { infarction, angina pectoris, }\end{array}$ & 141 subjects & $\begin{array}{l}\text { Cardiovascular parameters (MI, stroke, CABG+PCI, } \\
\text { Nonfatal CV events, CV mortality, Non-CV mortality) } \\
\text { • From the letters of the primary care physicians, } \\
\text { hospital discharge summaries, or other } \\
\text { consultants' reports. } \\
\text { Lab data (HbA1c, SBP, DBP, LDL, GFR, and } \\
\text { albumin/creatinine) }\end{array}$ \\
\hline
\end{tabular}


Table 1: Characteristics of studies investigating goals in people with diabetes (cont.)

\begin{tabular}{|c|c|c|c|c|c|}
\hline & & & $\begin{array}{l}\text { vascular surgery, stroke, or } \\
\text { any systemic or malignant } \\
\text { disease. }\end{array}$ & & \\
\hline $\begin{array}{l}\text { Olivarius } N F \\
\text { et al. }(2001)^{18}\end{array}$ & $\begin{array}{l}\text { Randomized } \\
\text { controlled trial }\end{array}$ & $\begin{array}{l}\text { To assess the effect of a multifaceted } \\
\text { intervention directed at general } \\
\text { practitioners on six year mortality, } \\
\text { morbidity, and risk factors of patients } \\
\text { with newly diagnosed type } 2 \\
\text { diabetes. }\end{array}$ & $\begin{array}{l}\text { Includion: newly diagnosed } \\
\text { type } 2 \text { diabetes who survived } \\
\text { until } 6 \text { year follow up, and > } \\
40 \text { y/o }\end{array}$ & 874 subjects & $\begin{array}{l}\text { Predefined primary outcomes: overall mortality and } \\
\text { incidences of diabetic retinopathy, urinary albumin } \\
\text { concentration }>15 \mathrm{mg} / \mathrm{l} \text {, myocardial infarction, and } \\
\text { stroke in patients without these outcomes at baseline. } \\
\text { Secondary outcomes: new peripheral neuropathy, } \\
\text { angina pectoris, intermittent claudication, and } \\
\text { amputation. } \\
\text { Tertiary outcomes: levels of risk factors included in } \\
\text { patients' goals. }\end{array}$ \\
\hline
\end{tabular}

HbA1c: Glycosylated Hemoglobin

LDL: Low-Density Lipoprotein

BP: Blood Pressure

SBP: Systolic Blood Pressure

DBP: Diastolic Blood Pressure

MI: Myocardial Infarction

CABG: Coronary Artery Bypass Graft

PCI: Percutaneous Coronary Intervention

CV: Cardiovascular.

GFR: Glomerular Filtration rate 


\begin{tabular}{|c|c|c|}
\hline AUTHOR & $\begin{array}{c}\text { MAJOR FINDING(S) / RESULTS (PRIMARILY WITH RESPECT TO } \\
\text { DEPRESSION) }\end{array}$ & STUDY NOVELTY / COMMENTS \\
\hline $\begin{array}{l}\text { Rush WA et } \\
\text { al. }(2008)^{51}\end{array}$ & $\begin{array}{l}\text { - Diabetes patients with depression symptoms were less likely to be at their glucose goal } \\
\text { (43\% vs 50\%; } \mathrm{P}=.0176 \text { ) but more likely to be at their SBP goal (57\% vs 51\%; P = } \\
.0435) \text {. } \\
\text { - The association between lipids and depression symptoms was related to a lower rate for } \\
\text { low-density lipoprotein testing (56\% vs } 68 \% \text {; }<\text {.0001). } \\
\text { - Treatment with antidepressants resulted in a greater percentage achieving glucose and } \\
\text { blood pressure goals but not lipid goals. }\end{array}$ & $\begin{array}{l}\text { - Depression seems to have a variable impact on achieving these } \\
\text { clinical goals, perhaps because the goals have differing } \\
\text { measurement logistics and biological profiles. } \\
\text { - Depression symptoms make it harder to reach glucose goals but } \\
\text { that treatment with an antidepressant may ameliorate this effect. }\end{array}$ \\
\hline $\begin{array}{l}\text { Morrow AS et } \\
\text { al. }(2008)^{13}\end{array}$ & $\begin{array}{l}\text { - Primary life and health goals reported by participants: Longevity, spend time with } \\
\text { family, improve or maintain physical functioning, maintain independence, improve } \\
\text { diabetes care } \\
\text { (improve lifestyle (diet, exercise, weight), control sugars, avoid complications) } \\
\text { - Factors influencing diabetes self-care goals: Health care providers, ancillary and outside } \\
\text { resources, family, diabetes discordant illnesses, and retirement. } \\
\text { - Functional capabilities and social support were key factors in the ways that older adults } \\
\text { described the relationship between self-management of diabetes and their broader goals. }\end{array}$ & $\begin{array}{l}\text { - Limitation: 1) generalizability } \\
\text { - The language used to describe health goals was often } \\
\text { indistinguishable from that used to describe life goals. } \\
\text { - For goal-setting to be effective, patients and caregivers must feel } \\
\text { confident in performing the necessary self-management steps and } \\
\text { must feel that the specific self-management goal is related to } \\
\text { one's overall life goals as well. }\end{array}$ \\
\hline $\begin{array}{l}\text { Estabrooks } \\
\text { PA et al. } \\
(2005)^{15}\end{array}$ & $\begin{array}{l}\text { - At baseline, participants who selected goals to increase physical activity, to reduce fat } \\
\text { consumption, or to increase fruits and vegetables intake were significantly less active, } \\
\text { consumed more dietary fat, and ate fewer fruits and vegetables, respectively . } \\
\text { - Participants who selected a reduced-fat goal showed a significantly larger decrease than } \\
\text { did those who selected a goal for physical activity or for fruits and vegetables. } \\
\text { - Participants who selected a goal for fruits and vegetables showed significant increase in } \\
\text { fruits and vegetables consumption. } \\
\text { - Participants who selected a goal for physical activity demonstrated significant increase } \\
\text { in days of moderate and vigorous physical activity. }\end{array}$ & $\begin{array}{l}\text { - When participants are provided with information on health } \\
\text { behavior status and an option of behavioral goals for managing } \\
\text { type } 2 \text { diabetes, they will select personally appropriate goals, } \\
\text { resulting in significant behavioral changes over a 6-month period }\end{array}$ \\
\hline $\begin{array}{l}\text { Huang ES et } \\
\text { al. }(2005)^{14}\end{array}$ & $\begin{array}{l}\text { - The majority of patients expressed their healthcare goals in a social and functional } \\
\text { language, in contrast to the biomedical language of risk factor control and complication } \\
\text { prevention, even when specifically asked about goals for diabetes mellitus care. } \\
\text { - Patient's predominant healthcare goals centered on maintaining their independence and } \\
\text { their activities of daily living ( } 71 \%) \text {. } \\
\text { - Medical experiences of friends and family (50\%), social comparison with peers (7\%), } \\
\text { and medical professionals (43\%) shaped patients' goals. } \\
\text { - Self-reported medication adherence and glucose monitoring was high, but more than }\end{array}$ & $\begin{array}{l}\text { - Providers could enhance their communication about such medical } \\
\text { decisions by exploring patients’ specific circumstances and } \\
\text { reframing diabetes mellitus treatment goals in patients' own } \\
\text { language. These may be crucial steps to developing successful } \\
\text { individualized care plans. }\end{array}$ \\
\hline
\end{tabular}




\begin{tabular}{|c|c|c|}
\hline & $\begin{array}{l}\text { one-quarter of patients failed to adhere to any dietary recommendations, and one-third } \\
\text { failed to adhere to their exercise regimens. }\end{array}$ & \\
\hline $\begin{array}{l}\text { Rachmani } R \\
\text { et al. }(2005)^{17}\end{array}$ & $\begin{array}{l}\text { - There were } 80 \text { cardiovascular events ( } 8 \text { deaths) in the control group versus } 47 \text { events ( } 5 \\
\text { deaths) in the intervention group }(\mathrm{P}=0.001) \text {. The relative risk (RR) over } 8 \text { yr for a } \\
\text { cardiovascular event in the intervention group versus the control group was } 0.65 \text { ( } 95 \% \\
\text { confidence interval, } 0.89 \text { to } 0.41) \text {. } \\
\text { - There were } 17 \text { and } 8 \text { cases of stroke in the control and intervention groups, respectively } \\
\text { (P = 0.05). RR for stroke was } 0.47 \text { ( } 95 \% \text { confidence interval, } 0.85 \text { to } 0.32 \text { ). } \\
\text { - In the control group, } 14 \text { patients developed overt nephropathy ( } 4 \text { ESRD) versus } 7 \text { (1 } \\
\text { ESRD) in the intervention group (P = 0.05). } \\
\text { - Throughout the study period, BP, LDL cholesterol, and HbA1c were significantly lower } \\
\text { in the intervention group than in the control patients. }\end{array}$ & $\begin{array}{l}\text { - Well informed and motivated patients were more successful in } \\
\text { obtaining and maintaining good control of their risk factors, } \\
\text { resulting in reduced cardiovascular risk and slower progression of } \\
\text { microvascular disease. }\end{array}$ \\
\hline $\begin{array}{l}\text { Olivarius NF } \\
\text { et al. }(2001)^{18}\end{array}$ & $\begin{array}{l}\text { - Predefined non-fatal outcomes and mortality were the same in both groups. } \\
\text { - The following risk factor levels were lower for intervention patients than for comparison } \\
\text { patients (median values): fasting plasma glucose concentration ( } 7.9 \mathrm{vs.} 8.7 \mathrm{mmol} / \mathrm{l}, \mathrm{P}= \\
0.0007), \mathrm{HbA1c}(8.5 \% \mathrm{vs.} 9.0 \%, \mathrm{P}<0.0001 \text {; reference range } 5.4-7.4 \%) \text {, systolic blood } \\
\text { pressure ( } 145 \mathrm{vs.} 150 \mathrm{~mm} \mathrm{Hg}, \mathrm{P}=0.0004) \text {, and cholesterol concentration (6.0 vs. } 6.1 \\
\text { mmol/l, P = 0.029, adjusted for baseline concentration). } \\
\text { - Both groups had lost weight since diagnosis ( } 2.6 \mathrm{v} 2.0 \mathrm{~kg} \text { ). } \\
\text { - Metformin was the only drug used more frequently in the intervention group ( } 24 \% \\
\text { (110/459) vs. } 15 \%(61 / 415) \text { ). } \\
\text { - Intervention doctors arranged more follow up consultations, referred fewer patients to } \\
\text { diabetes clinics, and set more optimistic goals. }\end{array}$ & $\begin{array}{l}\text { - In primary care, use of the model (individualised goals with } \\
\text { educational and surveillance support) may reduce risk factors to a } \\
\text { level that has been shown to have a beneficial effect on the } \\
\text { development of diabetic complications without adverse weight } \\
\text { gain. }\end{array}$ \\
\hline
\end{tabular}

HbA1c: Glycosylated Hemoglobin

LDL: Low-Density Lipoprotein

BP: Blood Pressure

SBP: Systolic Blood Pressure

DBP: Diastolic Blood Pressure

ESRD: End Stage Renal Disease 
Table 3: Characteristics of studies investigating barriers to self-care behaviors in people with diabetes

\begin{tabular}{|c|c|c|c|c|c|}
\hline AUTHOR & $\begin{array}{l}\text { STUDY } \\
\text { DESIGN }\end{array}$ & STUDY AIM & POPULATION & $\begin{array}{l}\text { SAMPLE } \\
\text { SIZE }\end{array}$ & MEASUREMENTS \\
\hline $\begin{array}{l}\text { Vijan S et al. } \\
(2005)^{25}\end{array}$ & $\begin{array}{l}\text { Cross- } \\
\text { sectional study }\end{array}$ & $\begin{array}{l}\text { To evaluate, both quantitatively and } \\
\text { qualitatively, barriers to following } \\
\text { dietary recommendations in people } \\
\text { with type } 2 \text { diabetes }\end{array}$ & $\begin{array}{l}\text { People were recruited from the } \\
\text { primary care population of a } \\
\text { large academic medical centre } \\
\text { and two VA hospitals. } \\
\text { Exclusion: those were } \\
\text { diagnosed with diabetes } \\
\text { prior to } 30 \mathrm{y} / \mathrm{o}\end{array}$ & 197 subjects & $\begin{array}{l}\text { Quantitative phase } \\
\text { Patient attitudes towards hypoglycaemic treatments } \\
\text { - A mailed, self-administered 50-question survey } \\
\text { - Ratings of the burden of diabetes therapies on a } \\
\text { seven-point scale (from } 0=\text { do not dislike at all to } \\
6 \text { = dislike very much) } \\
\text { Qualitative phase } \\
\text { Patient views towards diabetes care and barriers to } \\
\text { follow interventions } \\
\text { - Six focus group with 6-12 participants in each }\end{array}$ \\
\hline $\begin{array}{l}\text { Wagner J et } \\
\text { al. }(2005)^{26}\end{array}$ & $\begin{array}{l}\text { Cross- } \\
\text { sectional study }\end{array}$ & $\begin{array}{l}\text { To test the hypothesis that } \\
\text { invasiveness is a barrier to SMBG }\end{array}$ & $\begin{array}{l}\text { Adults with diabetes attending } \\
\text { the 2002, 2003, and } 2004 \\
\text { American Diabetes } \\
\text { Association “Diabetes Expos” } \\
\text { (health fairs) held at } \\
\text { convention centers of large, } \\
\text { northeastern cities. }\end{array}$ & $\begin{array}{l}339 \text { subjects } \\
\text { (subsample= } \\
32 \text { subjects) }\end{array}$ & $\begin{array}{l}\text { Anxiety regarding insulin injecting and SMBG } \\
\text { - The Diabetes Fear of Injecting and Self-Testing } \\
\text { Questionnaire (D-FIST) } \\
\text { Hassle/burden regarding SMBG } \\
\text { • The Diabetes Hassles Scale } \\
\text { - SMBG routine burden and non-routine burden } \\
\text { Knowledge about the link between glycemic control } \\
\text { and long-term vascular complications of diabetes. } \\
\text { • The Diabetes Heart Disease Facts Questionnaire } \\
\text { Percentage of SMBG adherence } \\
\text { • Self-reported No. of SMBG / recommended No. of } \\
\text { SMBG } \\
\text { - Meter-recorded No. of SMBG / recommended No. } \\
\text { of SMBG } \\
\text { Invasiveness as a barrier to SMBG } \\
\text { - Measure of Invasiveness as a reason for Skipping } \\
\text { SMBG (MISS) } \\
\text { - A higher score on the MISS reflects the tendency } \\
\text { to miss or skip SMBG because of the invasiveness } \\
\text { of the procedure. }\end{array}$ \\
\hline $\begin{array}{l}\text { Nagelkerk J et } \\
\text { al. }(2006)^{27}\end{array}$ & $\begin{array}{l}\text { Cross- } \\
\text { sectional study }\end{array}$ & $\begin{array}{l}\text { To describe the perceived barriers to } \\
\text { self-management of adults with type } \\
2 \text { diabetes in a rural setting and to } \\
\text { identify effective strategies in self- } \\
\text { management to highlight } \\
\text { infrastructure needs or changes in }\end{array}$ & $\begin{array}{l}\text { Inclusion: type } 2 \text { diabetes, } \geq \\
21 \text { y/o, having a telephone, } \\
\text { and being able to read, write } \\
\text { and speak English. }\end{array}$ & 24 subjects & $\begin{array}{l}\text { The focus group interview schedule was developed } \\
\text { using the key-informant technique, where three } \\
\text { individuals with a special interest in diabetes were } \\
\text { interviewed using open-ended questions. Key } \\
\text { concepts emerged which were included in the focus } \\
\text { group scheme. }\end{array}$ \\
\hline
\end{tabular}


Table 3: Characteristics of studies investigating barriers to self-care behaviors in people with diabetes (cont.)

\begin{tabular}{|c|c|c|c|c|c|}
\hline & & $\begin{array}{l}\text { clinical practice that would facilitate } \\
\text { the integration of diabetes self- } \\
\text { management. }\end{array}$ & & & \\
\hline $\begin{array}{l}\text { Morrow AS et } \\
\text { al. }(2008)^{13}\end{array}$ & $\begin{array}{l}\text { Cross- } \\
\text { sectional study }\end{array}$ & $\begin{array}{l}\text { To investigate the life and health } \\
\text { goals of older adults with diabetes, } \\
\text { and explore the factors that influence } \\
\text { their diabetes self-management. }\end{array}$ & $\begin{array}{l}\text { People from outpatient clinics } \\
\text { in the Houston area } \\
\text { Inclusion: type } 2 \text { diabetes, } \geq \\
55 \mathrm{y} / \mathrm{o} \text {, hypertension, and at } \\
\text { least one other chronic } \\
\text { comorbidity }\end{array}$ & 24 subjects & $\begin{array}{l}\text { Qualitative in-depth interviews } \\
\text { • Prior to the interview, information about people's } \\
\text { medical history, ability to perform activities of } \\
\text { daily living, and demographic characteristics was } \\
\text { collected using questionnaires administered by } \\
\text { investigators. } \\
\text { - Health care goals, effects of diabetes and other } \\
\text { chronic conditions on daily life, self-management } \\
\text { practices, and communication with health care } \\
\text { providers were asked using interview guide. }\end{array}$ \\
\hline $\begin{array}{l}\text { Daly JM et al. } \\
(2009)^{28}\end{array}$ & $\begin{array}{l}\text { Cross- } \\
\text { sectional study }\end{array}$ & $\begin{array}{l}\text { To determine (1) which barriers to } \\
\text { diabetes management were } \\
\text { associated with the problem } \\
\text { behaviors and (2) which patient } \\
\text { behaviors and barriers are associated } \\
\text { with diabetes control as measured by } \\
\text { glycosylated hemoglobin (HbA1c). }\end{array}$ & $\begin{array}{l}\text { People being followed in } \\
\text { primary care outpatient clinics } \\
\text { at a midwestern medical } \\
\text { center } \\
\text { Inclusion: type } 2 \text { diabetes, } \\
\text { regular clinic patients ( } \geq 2 \\
\text { outpatient visits within the } \\
\text { previous } 12 \text { months), and } \\
\text { having HbA1c test within } \\
\text { the previous } 3 \text { months }\end{array}$ & 253 subjects & $\begin{array}{l}\text { Diabetes self-care behaviors and barriers } \\
\text { - } 141 \text { questions in } 7 \text { domains } \\
\text { - Self-report } \\
\text { - Self-care behaviors were classified in } 2 \text { ways: (1) } \\
\text { percentage of time the people adhered to } \\
\text { medication, meal plan, exercise, and glucose } \\
\text { testing plans during the past month, and (2) the } \\
\text { level of satisfaction with each of the preceding } \\
\text { domains. From these } 2 \text { measures, a combined } \\
\text { dichotomous adherence-satisfaction score for each } \\
\text { domain was created. } \\
\text { - Barriers to each self-care behavior were } \\
\text { dichotomous. } \\
\text { - Depressive symptoms were evaluated using self- } \\
\text { reported 9-item Patient Health Questionnaire } \\
\text { (PHQ-9) } \\
\text { - Physical and mental health was evaluated using } \\
\text { 12-item Short-Form Health Survey (SF-12) } \\
\text { HbA1c } \\
\text { • Chart review }\end{array}$ \\
\hline
\end{tabular}

SMBG: Self-Monitoring of Blood Glucose 


\begin{tabular}{|c|c|c|}
\hline AUTHOR & $\begin{array}{l}\text { MAJOR FINDING(S) / RESULTS (PRIMARILY WITH RESPECT TO } \\
\text { DEPRESSION) }\end{array}$ & STUDY NOVELTY / COMMENTS \\
\hline $\begin{array}{l}\text { Vijan S et al. } \\
(2005)^{25}\end{array}$ & $\begin{array}{l}\text { Quantitative phase } \\
\text { - Moderate diet was seen as a greater burden than oral agents (median } 1 \text { vs. } 0, \mathrm{P}=0.001 \text { ), } \\
\text { but less of a burden than insulin (median } 1 \text { vs. } 4, \mathrm{P}<0.001) \text {. } \\
\text { - A strict diet aimed at weight loss was rated as being similarly burdensome to insulin } \\
\text { (median } 4 \text { vs. } 4, \mathrm{P}=\mathrm{NS} \text { ). } \\
\text { - Self-reported adherence was much higher for both pills and insulin than it was for a } \\
\text { moderate diet. } \\
\text { Qualitative phase } \\
\text { - The most commonly identified barrier was the cost ( } 14 / 14 \text { reviews), followed by small } \\
\text { portion sizes (13/14 reviews), support and family issues ( } 13 / 14 \text { reviews), and quality of } \\
\text { life and lifestyle issues ( } 12 / 14 \text { reviews). } \\
\text { - People in the urban site, who were predominantly African-American, noted greater } \\
\text { difficulties in communicating with their provider about diet and social circumstances, } \\
\text { and also that the rigid schedule of a diabetes diet was problematic. }\end{array}$ & $\begin{array}{l}\text { - Limitation: 1) selected populations used, 2) low (54\%) response } \\
\text { rate of survey, and 3) no causal inference due to cross-sectional } \\
\text { study. } \\
\text { - Interventions aimed at improving people's ability to modify their } \\
\text { diet need to take account of people’s preferences and cultural, } \\
\text { racial, or economic variation. } \\
\text { - Treatment guidelines need to consider people's preferences and } \\
\text { barriers when setting goals for treatment. }\end{array}$ \\
\hline $\begin{array}{l}\text { Wagner J et } \\
\text { al. }(2005)^{26}\end{array}$ & $\begin{array}{l}\text { - } 63 \% \text { of respondents reported skipping SMBG because of the invasiveness of the } \\
\text { procedure. } \\
\text { - MISS scores were negatively related to percent adherence to healthcare provider SMBG } \\
\text { recommendations as measured by memory function of automated meters (Spearman's } r \\
=0.47, \mathrm{P}<0.01 \text { ) and absolute SMBG frequency regardless of SMBG recommendations } \\
\text { (Spearman's } \mathrm{r}=0.11, \mathrm{P}<0.05 \text { ) } \\
\text { - MISS scores were positively correlated with SMBG anxiety (Spearman's } \mathrm{r}=0.50, \mathrm{P}< \\
0.01 \text { ) even though high anxious participants were deleted (Spearman's } \mathrm{r}=0.28, \mathrm{P}< \\
0.01 \text { ). } \\
\text { - MISS scores were also correlated with the degree to which people find routine and non- } \\
\text { routine SMBG checks a burden (routine } \mathrm{r}=0.38, \mathrm{P}<0.01 \text {; non-routine } \mathrm{r}=0.45, \mathrm{P}< \\
0.01 \text { ). } \\
\text { - Participants with less knowledge about the importance of glycemic control in the } \\
\text { development of diabetes vascular complications had higher MISS scores. }\end{array}$ & $\begin{array}{l}\text { - Limitation: Since participants may have higher adherence to } \\
\text { SMBG compared to general diabetes patients (volunteer bias), it } \\
\text { would be harder to find an effect for invasiveness as a barrier to } \\
\text { SMBG. }\end{array}$ \\
\hline $\begin{array}{l}\text { Nagelkerk } J \\
\text { et al. }(2006)^{27}\end{array}$ & $\begin{array}{l}\text { - Perceived barriers to self-management in rank order } \\
\text { 1. Lack of knowledge and understanding of a specific diet plan } \\
\text { 2. Lack of individualized and coordinated care } \\
\text { 3. Helplessness and frustration from lack of glycaemic control despite adherence } \\
\text { 4. Limited resources to obtain recommended equipment, medicines, laboratory tests and } \\
\text { provider services } \\
\text { 5. Inconvenient, costly and non-specific group education sessions } \\
\text { 6. Difficulty in remembering to take medications, lack of knowledge about medication } \\
\text { action, side effects, schedules, and adjustments }\end{array}$ & $\begin{array}{l}\text { - Limitation: 1) one clinical practice with a fairly homogeneous } \\
\text { sample, and 2) no causal inference due to cross-sectional study. } \\
\text { - Identifying individual barriers, facilitating the acquisition of a } \\
\text { support network, developing collaborative relationships with } \\
\text { healthcare providers and maintaining a positive attitude are key } \\
\text { strategies in facilitating integration. }\end{array}$ \\
\hline
\end{tabular}


Table 4: Major findings of studies investigating barriers to self-care behaviors in people with diabetes (cont.)

\begin{tabular}{|c|c|c|}
\hline & $\begin{array}{l}\text { - Effective strategies in self-management by rank order } \\
\text { 1. Developing a collaborative relationship with a healthcare provider } \\
\text { 2. Maintaining a positive attitude that prompts proactive learning } \\
\text { 3. Having a support person who gives encouragement and assistance and facilitates self- } \\
\text { management } \\
\text { 4. Acquiring adequate resources for self-management } \\
\text { 5. Maintaining routine medication administration times and routines } \\
\text { 6. Participating in group education that encourages questions and discussion of feelings } \\
\text { and fears }\end{array}$ & \\
\hline $\begin{array}{l}\text { Morrow AS et } \\
\text { al. }(2008)^{13}\end{array}$ & $\begin{array}{l}\text { - Factors influencing diabetes self-care goals: Health care providers, ancillary and outside } \\
\text { resources, family, diabetes discordant illnesses (barrier), and retirement (barrier). } \\
\text { - Functional capabilities and social support were key factors in the ways that older adults } \\
\text { described the relationship between self-management of diabetes and their broader goals. }\end{array}$ & - Limitation: 1) generalizability \\
\hline $\begin{array}{l}\text { Daly JM et } \\
\text { al. }(2009)^{28}\end{array}$ & $\begin{array}{l}\text { - The main barriers across most self-care behaviors were cost (most common) and } \\
\text { depression. } \\
\text { - Higher HbA1c levels were strongly associated with the belief that type } 2 \text { diabetes is a } \\
\text { serious problem }(\mathrm{P}=0.049) \text { and depression }(\mathrm{P}=0.005) \text {. Lower HbA1c levels were } \\
\text { significantly associated with being married }(\mathrm{P}=0.016) \text { and greater self-reported } \\
\text { adherence-satisfaction with taking medication }(\mathrm{P}=0.001) \text { and testing blood glucose }(\mathrm{P} \\
=0.042) \text {. } \\
\text { - The PHQ-9 depression score was significantly correlated with financial barriers, with a } \\
\text { coefficient of } 0.45(\mathrm{P}=0.0001) \text {. In the } t \text { test, } \mathrm{PHQ}-9 \text { mean score was } 11.51 \text { for people } \\
\text { with financial barriers compared with } 5.33 \text { for those without financial barriers }(\mathrm{P}= \\
0.0001) \text {. }\end{array}$ & $\begin{array}{l}\text { - Limitation: 1) small sample size, 2) no causal inference due to } \\
\text { cross-sectional study, 3) self-report measurement }\end{array}$ \\
\hline
\end{tabular}

SMBG: Self-Monitoring of Blood Glucose 
Table 5: Characteristics of studies investigating effects of depression on self-care behaviors in people with diabetes

\begin{tabular}{|c|c|c|c|c|c|c|}
\hline AUTHOR & $\begin{array}{c}\text { STUDY } \\
\text { DESIGN }\end{array}$ & STUDY AIM & POPULATION & $\begin{array}{l}\text { SAMPLE } \\
\text { SIZE }\end{array}$ & $\begin{array}{l}\text { DEPRESSION } \\
\text { ASSESSMENT }\end{array}$ & SELF-CARE ASSESSMENT \\
\hline $\begin{array}{l}\text { Ciechanowski } \\
\text { PS et al. } \\
(2000)^{37}\end{array}$ & $\begin{array}{l}\text { Cross- } \\
\text { sectional study }\end{array}$ & $\begin{array}{l}\text { To explore the impact } \\
\text { of depressive } \\
\text { symptoms in primary } \\
\text { care patients with } \\
\text { diabetes on diabetes } \\
\text { self-care, adherence } \\
\text { to medication } \\
\text { regimens, } \\
\text { functioning, and } \\
\text { health care costs. }\end{array}$ & $\begin{array}{l}\text { Patients from } 2 \text { primary care } \\
\text { clinics of the Group Health } \\
\text { Cooperative (GHC) in Puget } \\
\text { Sound, Washington. } \\
\text { Inclusion: types } 1 \text { and } 2 \\
\text { diabetes, }>18 \text { years old, and } \\
\geq 2 \text { years enrollment. } \\
\text { Exclusion: severe cognitive } \\
\text { deficit. }\end{array}$ & 367 subjects & $\begin{array}{l}\text { Hopkins Symptom } \\
\text { Checklist-20, Revised } \\
\text { (HSCL-20) } \\
\text { - } 20 \text {-item questionnaire } \\
\text { - Depression and } \\
\text { additional symptom } \\
\text { subscales } \\
\text { - } 3 \text { tertiles of depression: } \\
\text { low, medium, and high } \\
\text { - Self-report }\end{array}$ & $\begin{array}{l}\text { Diet (amount and type), exercise, and } \\
\text { SMBG } \\
\text { - } 12 \text {-item questionnaire } \\
\text { - Percentage of activities } \\
\text { recommended by the physician that } \\
\text { were actually performed. } \\
\text { - Self-report } \\
\text { Adherence to oral hypoglycemic } \\
\text { regimens } \\
\text { - Automated data } \\
\text { - Percentage of days in oral } \\
\text { hypoglycemic therapy interruption }\end{array}$ \\
\hline $\begin{array}{l}\text { Ciechanowski } \\
\text { PS et al. } \\
(2003)^{38}\end{array}$ & $\begin{array}{l}\text { Cross- } \\
\text { sectional study }\end{array}$ & $\begin{array}{l}\text { To determine if } \\
\text { diabetes self-care } \\
\text { behaviors, physical } \\
\text { functioning, diabetes } \\
\text { symptom reporting, } \\
\text { and glucose control } \\
\text { are significantly } \\
\text { associated with } \\
\text { depressive symptoms } \\
\text { in both type } 1 \text { and } 2 \\
\text { diabetes. }\end{array}$ & $\begin{array}{l}\text { This study was carried out in a } \\
\text { tertiary care specialty clinic at } \\
\text { the University of Washington } \\
\text { Diabetes Care Center (DCC), } \\
\text { Seattle, Washington. } \\
\text { Inclusion: type } 1 \text { or type } 2 \\
\text { diabetes, enrollment in both } \\
1998 \text { and } 1999, \geq 18 \text { years } \\
\text { old } \\
\text { Exclusion: severe cognitive } \\
\text { deficits }\end{array}$ & $\begin{array}{l}\text { Type } 1= \\
276 \text { subjects } \\
\text { Type } 2= \\
199 \text { subjects }\end{array}$ & $\begin{array}{l}\text { Hopkins Symptom } \\
\text { Checklist-20, Revised } \\
\text { (HSCL-20) } \\
\text { - 20-item questionnaire } \\
\text { - Depression and } \\
\text { additional symptom } \\
\text { subscales } \\
\text { - Self-report }\end{array}$ & $\begin{array}{l}\text { Diet (amount and type), exercise, and } \\
\text { SMBG } \\
\text { - 12-item questionnaire } \\
\text { - Percentage of activities } \\
\text { recommended by the physician that } \\
\text { were actually performed. } \\
\text { - Self-report }\end{array}$ \\
\hline $\begin{array}{l}\text { Lin EH et al. } \\
(2004)^{39}\end{array}$ & $\begin{array}{l}\text { Cross- } \\
\text { sectional study }\end{array}$ & $\begin{array}{l}\text { To assess whether } \\
\text { diabetes self-care, } \\
\text { medication } \\
\text { adherence, and use of } \\
\text { preventive services } \\
\text { were associated with } \\
\text { depressive illness. }\end{array}$ & $\begin{array}{l}\text { Nine Group Health } \\
\text { Cooperative primary care } \\
\text { clinics in western Washington } \\
\text { were selected for the study. } \\
\text { Inclusion: type } 1 \text { or type } 2 \\
\text { diabetes } \\
\text { Exclusion: cognitive } \\
\text { impairment }\end{array}$ & $\begin{array}{l}4463 \\
\text { subjects } \\
\text { (Type 1= } \\
95.6 \% \\
\text { Type 2 = } \\
4.4 \%)\end{array}$ & $\begin{array}{l}\text { Patient Health } \\
\text { Questionnaire } \\
\text { - According to DSM-IV } \\
\text { criteria } \\
\text { - A continuous severity } \\
\text { score. } \\
\text { - Structured interviews } \\
\text { (78\% sensitivity and } \\
\text { 98\% specificity). } \\
\text { - Self-report }\end{array}$ & $\begin{array}{l}\text { Diet, exercise, SMBG, foot checks, and } \\
\text { smoking status } \\
\text { • Recently revised version of the } \\
\text { Summary of Diabetes Self-Care } \\
\text { Activities (SDSCA) } \\
\text { - Number of days in the prior week } \\
\text { subject engaged in a certain activity } \\
\text { - Self-report } \\
\text { Adherence to oral hypoglycemic } \\
\text { medicines } \\
\text { - GHC automated pharmacy database } \\
\text { - Percentage of non-adherence days } \\
\text { Preventive services (HbA1c test, retinal } \\
\text { exam, and microalbumin urine test) }\end{array}$ \\
\hline
\end{tabular}


Table 5: Characteristics of studies investigating effects of depression on self-care behaviors in people with diabetes (cont.)

\begin{tabular}{|c|c|c|c|c|c|c|}
\hline & & & & & & $\begin{array}{l}\text { - Automated diagnostic and } \\
\text { laboratory data }\end{array}$ \\
\hline $\begin{array}{l}\text { Park HS et al. } \\
(2004)^{40}\end{array}$ & $\begin{array}{l}\text { Cross- } \\
\text { sectional study }\end{array}$ & $\begin{array}{l}\text { To determine whether } \\
\text { depressive symptoms } \\
\text { are associated with } \\
\text { poor self-care } \\
\text { behaviors among } \\
\text { people with type } 2 \\
\text { diabetes }\end{array}$ & $\begin{array}{l}\text { People who visited the Ewha } \\
\text { Womans University Hospital, } \\
\text { Seoul, Republic of Korea, } \\
\text { Inclusion: type } 2 \text { diabetes } \\
\text { history of } 1-15 \text { years, and > } \\
30 \text { years old. } \\
\text { Exclusion: Advanced } \\
\text { diabetic complications, or a } \\
\text { history of psychiatric } \\
\text { treatment. }\end{array}$ & 168 subjects & $\begin{array}{l}\text { Centers for Epidemiologic } \\
\text { Studies-Depression (CES- } \\
\text { D) scales. } \\
\text { • Self-report }\end{array}$ & $\begin{array}{l}\text { Medication adherence, SMBG, diet, } \\
\text { exercise, and participation in patient } \\
\text { education programs } \\
\text { • Self-report } \\
\text { - Dichotomized into adherent or non- } \\
\text { adherent categories. }\end{array}$ \\
\hline $\begin{array}{l}\text { Kilbourne AM } \\
\text { et al. }(2005)^{43}\end{array}$ & $\begin{array}{l}\text { Prospective } \\
\text { cohort study }\end{array}$ & $\begin{array}{l}\text { To assessed the } \\
\text { association between } \\
\text { depression and } \\
\text { diabetes medication } \\
\text { adherence }\end{array}$ & $\begin{array}{l}\text { Veterans receiving primary } \\
\text { care at an urban Veterans } \\
\text { Administration facility in US } \\
\text { Inclusion: type } 2 \text { diabetes, } \\
\text { and taking oral } \\
\text { hypoglycemic therapy } \\
\text { medication } \\
\underline{\text { Exclusion: taking insulin }} \\
\text { only }\end{array}$ & 203 subjects & $\begin{array}{l}\text { Patient Health } \\
\text { Questionnaire (PHQ-9) } \\
\text { - At baseline } \\
\text { - Self-report } \\
\text { - The presence of the } \\
\text { nine symptoms of } \\
\text { depression } \\
\text { corresponding to } \\
\text { DSM-IV criteria } \\
\text { - Dichotomized variable } \\
\text { (sensitivity = 0.73 and } \\
\text { specificity = 0.94) }\end{array}$ & $\begin{array}{l}\text { Adherence to oral hypoglycemic } \\
\text { therapy } \\
\text { - Four sources: patient report, } \\
\text { provider report, electronic } \\
\text { monitoring caps (EMCs), and } \\
\text { pharmacy data }\end{array}$ \\
\hline $\begin{array}{l}\text { Kalsekar ID } \\
\text { et al. }(2006)^{42}\end{array}$ & $\begin{array}{l}\text { Retrospective } \\
\text { cohort study }\end{array}$ & $\begin{array}{l}\text { To examine the } \\
\text { impact of depression } \\
\text { on adherence to oral } \\
\text { hypoglycemic agents } \\
\text { in people newly } \\
\text { diagnosed with type } 2 \\
\text { diabetes }\end{array}$ & $\begin{array}{l}\text { People newly diagnosed with } \\
\text { type } 2 \text { diabetes during a } 4 \text { year } \\
\text { period (1998-2001) were } \\
\text { identified from a Medicaid } \\
\text { claims database. } \\
\text { Exclusion: } \geq 65 \text { years old, } \\
\text { people who took } \\
\text { troglitazone, people with } \\
\text { schizophrenia, bipolar } \\
\text { disorder, dementia, and } \\
\text { Alzheimer's disease }\end{array}$ & $\begin{array}{l}1326 \\
\text { subjects }\end{array}$ & 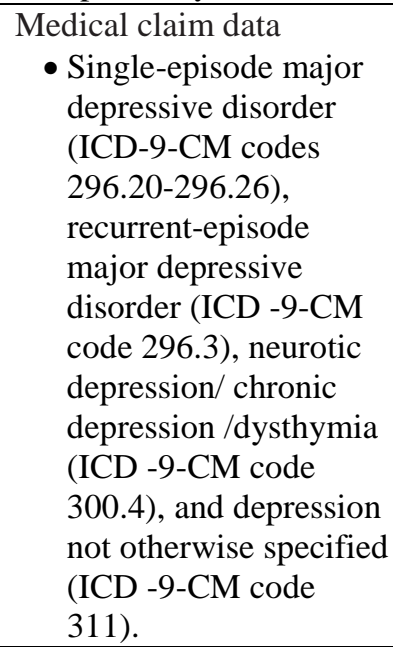 & $\begin{array}{l}\text { Adherence to oral hypoglycemic agents } \\
\text { - Prescription refill data } \\
\text { - } 12 \text { month follow-up period from the } \\
\text { index prescription } \\
\text { - MPR-1: a measure of medication } \\
\text { adherence in the period between the } \\
\text { first and last prescription fills } \\
\text { - MPR-2: a measure of medication } \\
\text { adherence in the period between the } \\
\text { index prescription and the end of the } \\
\text { follow-up period. People who } \\
\text { discontinued therapy after a single } \\
\text { prescription were included }\end{array}$ \\
\hline $\begin{array}{l}\text { Gonzalez JS } \\
\text { et al. }(2007)^{41}\end{array}$ & $\begin{array}{l}\text { Cross- } \\
\text { sectional study }\end{array}$ & $\begin{array}{l}\text { To examine the } \\
\text { association between }\end{array}$ & $\begin{array}{l}\text { People who were followed in } \\
\text { one of two outpatient primary }\end{array}$ & 879 subjects & $\begin{array}{l}\text { Harvard Department of } \\
\text { Psychiatry/National }\end{array}$ & Diet, exercise, SMBG, and foot care \\
\hline
\end{tabular}


Table 5: Characteristics of studies investigating effects of depression on self-care behaviors in people with diabetes (cont.)

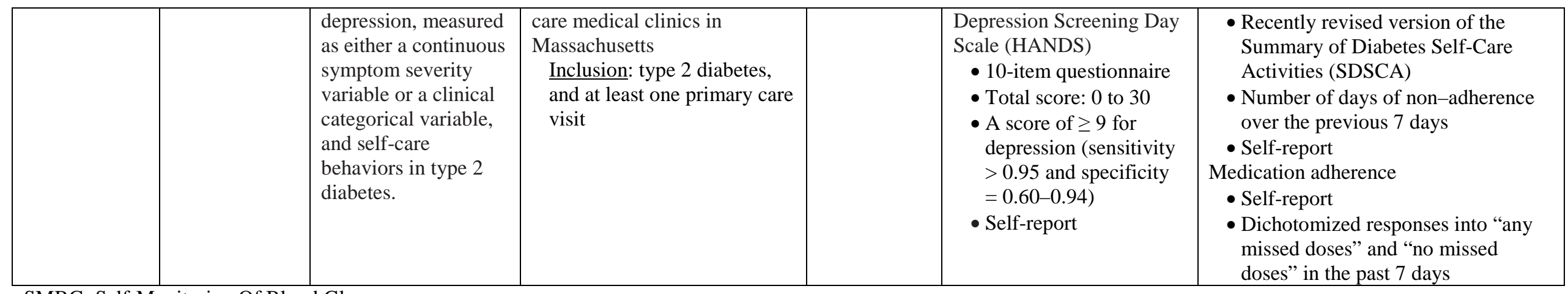

SMBG: Self-Monitoring Of Blood Glucose

MPR: Medication Possession Ratio 


\begin{tabular}{|c|c|c|}
\hline AUTHOR & $\begin{array}{c}\text { MAJOR FINDING(S) / RESULTS (PRIMARILY WITH RESPECT TO } \\
\text { DEPRESSION) }\end{array}$ & STUDY NOVELTY / COMMENTS \\
\hline $\begin{array}{l}\text { Ciechanowski } \\
\text { PS et al. } \\
(2000)^{37}\end{array}$ & $\begin{array}{l}\text { - Compared with people in the low-severity depression symptom tertile, those in the } \\
\text { medium- and high severity tertiles of depression were significantly less adherent to } \\
\text { dietary recommendations (diet amount or diet type). } \\
\text { - People in the high-severity tertile were significantly distinct from those in the low } \\
\text { severity tertile by having a higher percentage of days in non-adherence to oral } \\
\text { hypoglycemic regimens ( } 7.1 \% \text { vs. } 14.9 \%, \mathrm{P}=0.04) \text {. } \\
\text { - There is no effect of depression on exercise and glucose monitoring. }\end{array}$ & $\begin{array}{l}\text { - This study was probably the first one investigating the association } \\
\text { between depression and self-care behaviors. } \\
\text { - The severity of depression was divided into four level: none, low, } \\
\text { medium, and high }\end{array}$ \\
\hline $\begin{array}{l}\text { Ciechanowski } \\
\text { PS et al. } \\
(2003)^{38}\end{array}$ & $\begin{array}{l}\text { - Among people with type } 1 \text { and } 2 \text { diabetes, depressive symptoms were significantly } \\
\text { associated with lower adherence to diet amount }(\mathrm{P}<0.001) \text {, diet type }(\mathrm{P}<0.05) \text {, and } \\
\text { exercise regimens }(\mathrm{P}<0.01) \text {, but not significantly associated with glucose monitoring. }\end{array}$ & $\begin{array}{l}\text { - These associations were robust after controlling for diabetes type } \\
\text { and complications. } \\
\text { - This study was conducted in a tertiary care specialty clinic, which } \\
\text { may limit the generalizability to a typical primary care population. }\end{array}$ \\
\hline $\begin{array}{l}\text { Lin EH et al. } \\
(2004)^{39}\end{array}$ & $\begin{array}{l}\text { - Major depression was associated with unhealthy diet, less physical activity, smoking, } \\
\text { and lower adherence to oral hypoglycemic, antihypertensive, and lipid-lowering } \\
\text { medications. } \\
\text { - A slightly higher proportion of people with depression received no HbA1c test in the } \\
\text { prior year compared to those without depression. } \\
\text { - Depressed people and non-depressed people did not significantly differ from each other } \\
\text { with regard to home-glucose tests, foot checks, and other preventive diabetes services. }\end{array}$ & $\begin{array}{l}\text { - Depression appeared to influence patient-initiated activities (e.g., } \\
\text { exercise, diet, and medication adherence) more than physician- } \\
\text { initiated services (e.g., HbA1c test, retinal test, and microalbumin } \\
\text { test). }\end{array}$ \\
\hline $\begin{array}{l}\text { Park HS et } \\
\text { al. }(2004)^{40}\end{array}$ & $\begin{array}{l}\text { - Higher depressive-symptom scores were significantly associated with poor participation } \\
\text { in education programs (OR }=1.21,95 \% \mathrm{CI}=1.06-1.38) \text {, poor diet }(\mathrm{OR}=1.11,95 \% \mathrm{CI} \\
=1.01-1.22) \text {, and marginally with poor medication taking (OR }=1.14,95 \% \mathrm{CI}=1.00- \\
\text { 1.31). } \\
\text { - Depressive symptoms were not significantly associated with either SMBG or exercise. }\end{array}$ & $\begin{array}{l}\text { - This study was the only one conducted in Korea. } \\
\text { - This study also investigated the association between depression } \\
\text { and participation in education programs, which is one of the most } \\
\text { important behaviors for diabetes care. } \\
\text { - The lower rates of glucose monitoring in this study can be } \\
\text { explained by cost for glucometers, which was not covered by } \\
\text { insurance in Korea. }\end{array}$ \\
\hline $\begin{array}{l}\text { Kilbourne } \\
\text { AM et al. } \\
(2005)^{43}\end{array}$ & $\begin{array}{l}\text { - Depressed people were less likely to self-report good adherence }(\mathrm{P}=0.03) \text { and had a } \\
\text { lower median percentage of days with adequate medication coverage on the basis of } \\
\text { pharmacy refill data. } \\
\text { - After adjustment for alcohol use, cognitive impairment, age, and other medication use, } \\
\text { depression was still negatively associated with adequate adherence according to patient } \\
\text { report and pharmacy data. } \\
\text { - Depression showed no association with medication adherence on the basis of provider } \\
\text { or EMC data. }\end{array}$ & $\begin{array}{l}\text { - The generalizability of this study was limited because 1) the VA } \\
\text { healthcare system had unique features, such as the mail-order } \\
\text { pharmacy system and a comprehensive pharmacy database 2) it } \\
\text { only included the elder veteran population without female people. }\end{array}$ \\
\hline
\end{tabular}


Table 6: Major findings of studies investigating effects of depression on self-care behaviors in people with diabetes (cont.)

\begin{tabular}{|c|c|c|}
\hline & depressed people, after controlling for confounding factors. & \\
\hline $\begin{array}{l}\text { Gonzalez JS } \\
\text { et al. }(2007)^{41}\end{array}$ & $\begin{array}{l}\text { - After controlling for covariates, people with probable major depression reported } \\
\text { significantly fewer days' adherent to diet, exercise, and glucose self-monitoring } \\
\text { regimens }(\mathrm{P}<0.01) \text { and } 2.3 \text {-fold increased odds of missing medication doses in the } \\
\text { previous week (95\% CI 1.5-3.6, P }<0.001) \text { compared with all other respondents. } \\
\text { - Among the two-thirds of people not meeting the criteria for major depression (HANDS } \\
\text { score }<9, \mathrm{n}=709 \text { ), increasing HANDS scores were incrementally associated with } \\
\text { poorer self-care behaviors (P }<0.01) \text {. }\end{array}$ & $\begin{array}{l}\text { - These findings challenged the conceptualization of depression as } \\
\text { a categorical risk factor for non-adherence. } \\
\text { - Even low levels of depressive symptomatology were associated } \\
\text { with non-adherence to important aspects of diabetes self-care. }\end{array}$ \\
\hline
\end{tabular}

SMBG: Self-Monitoring Of Blood Glucose

MPR: Medication Possession Ratio 
Table 7: Characteristics of studies investigating depression treatment in people with diabetes and depression

\begin{tabular}{|c|c|c|c|c|c|}
\hline AUTHOR & $\begin{array}{c}\text { STUDY } \\
\text { DESIGN }\end{array}$ & STUDY AIM & POPULATION & SAMPLE SIZE & MEASUREMENTS \\
\hline $\begin{array}{l}\text { Lustman } \\
\text { PJ et al. } \\
(1997)^{48}\end{array}$ & $\begin{array}{l}\text { Randomized } \\
\text { controlled } \\
\text { trials }\end{array}$ & $\begin{array}{l}\text { To evaluate the effects of } \\
\text { nortriptyline on } \\
\text { depression and glycemic } \\
\text { control to see whether } \\
\text { depression in diabetes is } \\
\text { treatable and whether } \\
\text { restoring mental health } \\
\text { contributes to improved } \\
\text { medical outcome. } \\
\text { Intervention: nortriptyline } \\
\text { Control: placebo }\end{array}$ & $\begin{array}{l}\text { Inclusion: } 21 \text { to } 65 \text { y/o, type } 1 \text { or } \\
\text { type } 2 \text { diabetes, and relatively poor } \\
\text { control of diabetes (HbA1c } \geq 9 \% \text { ) } \\
\text { Exclusion: having history of bipolar } \\
\text { depression or any psychotic } \\
\text { disorder, and currently taking } \\
\text { psychoactive medications. }\end{array}$ & $\begin{array}{l}28 \text { depressed } \\
\text { subjects (14 } \\
\text { subjects in } \\
\text { nortriptyline } \\
\text { group and } 14 \\
\text { subjects in } \\
\text { placebo group); } \\
40 \text { non-depressed } \\
\text { subjects (12 } \\
\text { subjects in } \\
\text { nortriptyline } \\
\text { group and } 28 \\
\text { subjects in } \\
\text { placebo group) }\end{array}$ & $\begin{array}{l}\text { Depression: } \\
\text { - The major Axis I clinical syndromes were assessed } \\
\text { using the DIS (revised three version) and diagnosed } \\
\text { according to the criteria of the DSM-IIIR } \\
\text { - The severity of current depression symptoms was } \\
\text { measured using the BDI } \\
\text { Diabetes outcome: } \\
\text { - HbA1c } \\
\text { Adherence to medication: } \\
\text { - An electronic monitoring device was used } \\
\text { - Adherence = (the number of days the patient } \\
\text { removed the prescribed number of medication } \\
\text { dosages) } \div \text { (the total number of days in treatment) } \\
\text { Adherence to self-monitoring of blood glucose: } \\
\text { - An memory glucometer was used } \\
\text { - Weekly adherence = (the number of samples } \\
\text { measured) } \div \text { (the number of tests requested) }\end{array}$ \\
\hline $\begin{array}{l}\text { Lustman } \\
\text { PJ et al. } \\
(1998)^{49}\end{array}$ & $\begin{array}{l}\text { Randomized } \\
\text { controlled } \\
\text { trials }\end{array}$ & $\begin{array}{l}\text { To determine the } \\
\text { antidepressant efficacy of } \\
\text { cognitive behavior } \\
\text { therapy (CBT) added to } \\
\text { supportive diabetes } \\
\text { education, and whether } \\
\text { remission of depression is } \\
\text { associated with improved } \\
\text { glycemic control. } \\
\text { Intervention: CBT plus } \\
\text { diabetes education } \\
\text { Control: diabetes } \\
\text { education }\end{array}$ & $\begin{array}{l}\text { Inclusion: type } 2 \text { diabetes, } 21 \text { to } 70 \\
\text { y/o, and major depression } \\
\text { Exclusion: having a history of panic } \\
\text { disorder, bipolar depression, or any } \\
\text { psychotic disorder, currently taking } \\
\text { psychoactive medications. } \\
\text { Depression Identification: } \geq 14 \text { on } \\
\text { BDI }\end{array}$ & $\begin{array}{l}20 \text { subjects } \\
\text { receiving CBT } \\
\text { plus diabetes } \\
\text { education; } 22 \\
\text { subjects receiving } \\
\text { diabetes alone }\end{array}$ & $\begin{array}{l}\text { Depression: } \\
\text { - The major Axis I clinical syndromes were assessed } \\
\text { using the DIS (revised three version) and diagnosed } \\
\text { according to the criteria of the DSM-IIIR } \\
\text { - The severity of current depression symptoms was } \\
\text { measured using the BDI } \\
\text { Adherence to self-monitoring of blood glucose: } \\
\text { - An memory glucometer was used } \\
\text { - Weekly adherence = (the number of samples } \\
\text { measured) } \div \text { (the number of tests requested) }\end{array}$ \\
\hline $\begin{array}{l}\text { Williams } \\
\text { JW et al. } \\
(2004)^{50}\end{array}$ & $\begin{array}{l}\text { Randomized } \\
\text { controlled } \\
\text { trials }\end{array}$ & $\begin{array}{l}\text { To determine whether } \\
\text { enhancing care for } \\
\text { depression improves } \\
\text { affective and diabetic } \\
\text { outcomes in older adults } \\
\text { with diabetes and } \\
\text { depression. }\end{array}$ & $\begin{array}{l}\text { Inclusion: } \geq 60 \text { y/o, type } 1 \text { or type } 2 \\
\text { diabetes, and major depression or } \\
\text { dysthymic disorder } \\
\text { Exclusion: having a history of } \\
\text { bipolar disorder or psychosis, } \\
\text { ongoing treatment with a } \\
\text { psychiatrist, or severe cognitive }\end{array}$ & $\begin{array}{l}205 \text { subjects in } \\
\text { intervention } \\
\text { group; } 212 \\
\text { subjects in usual } \\
\text { group }\end{array}$ & $\begin{array}{l}\text { Depression: } \\
\text { - The severity of depressive symptoms were assessed } \\
\text { using the SCL-20 } \\
\text { - The diagnoses of major depression or dysthymia } \\
\text { were evaluated using the structured clinical } \\
\text { interview for DSM-IV }\end{array}$ \\
\hline
\end{tabular}


Table 7: Characteristics of studies investigating depression treatment in people with diabetes and depression (cont.)

\begin{tabular}{|c|c|c|c|c|c|}
\hline & & $\begin{array}{l}\text { Intervention: enhanced } \\
\text { depression care } \\
\text { (education, problem } \\
\text { solving, and } \\
\text { antidepressant) } \\
\text { Control: usual care }\end{array}$ & $\begin{array}{l}\text { impairment } \\
\text { Depression Identification: } \\
\text { According to the criteria of the } \\
\text { DSM-IV }\end{array}$ & & $\begin{array}{l}\text { Diabetes self-care (diet, exercise, glucose testing, } \\
\text { diabetes medication, and foot care): } \\
\text { - The } 12 \text {-item SDSCA, augmented by an item to } \\
\text { assess foot care } \\
\text { Diabetes outcome: } \\
\text { - HbA1c }\end{array}$ \\
\hline $\begin{array}{l}\text { Lin EH et } \\
\text { al. } \\
(2006)^{46}\end{array}$ & $\begin{array}{l}\text { Randomized } \\
\text { controlled } \\
\text { trials }\end{array}$ & $\begin{array}{l}\text { To examine the impact of } \\
\text { improved depression } \\
\text { treatment on self-care } \\
\text { behaviors } \\
\text { Intervention: improved } \\
\text { depression care } \\
\text { (pharmacotherapy and/or } \\
\text { problem solving) } \\
\text { Control: usual care }\end{array}$ & $\begin{array}{l}\text { Inclusion: } \geq 18 \text { y/o, diagnosed with } \\
\text { type } 1 \text { or type } 2 \text { diabetes and } \\
\text { depression } \\
\text { Exclusion: having gestational } \\
\text { diabetes, psychotic disorder, bipolar } \\
\text { disorder, use of mood-stabilizing or } \\
\text { antipsychotic medication, and } \\
\text { current care by a psychiatrist } \\
\text { Depression Identification: A score } \\
\text { of } 10 \text { or higher on the PHQ- } 9 \text { at the } \\
\text { initial screening and evidence of } \\
\text { persistent depression as measured } \\
\text { by a mean item score of } 1.1 \text { or } \\
\text { higher on the SCL-20 } 2 \text { weeks later. }\end{array}$ & $\begin{array}{l}164 \text { subjects in } \\
\text { intervention } \\
\text { group; } 165 \\
\text { subjects in usual } \\
\text { group }\end{array}$ & $\begin{array}{l}\text { Diet, exercise, blood glucose testing, foot checks, and } \\
\text { smoking } \\
\text { • The 12-item SDSCA } \\
\text { Medication adherence } \\
\text { - Automated pharmacy refill data of oral } \\
\text { hypoglycemic agents, lipid-lowering agents, and } \\
\text { angiotensin-converting enzyme inhibitors }\end{array}$ \\
\hline
\end{tabular}

DIS: National Institute of Mental Health Diagnostic Interview Schedule

DSM: Diagnostic and Statistical Manual of Mental Disorders

BDI: Beck Depression Inventory

PHQ-9: Patient Health Questionnaire-9

SCL-20: Hopkins Symptom Checklist-20

SDSCA: Summary of Diabetes Self-Care Activities 


\begin{tabular}{|c|c|c|}
\hline AUTHOR & $\begin{array}{c}\text { MAJOR FINDING(S) / RESULTS (PRIMARILY WITH RESPECT TO } \\
\text { DEPRESSION) }\end{array}$ & STUDY NOVELTY / COMMENTS \\
\hline $\begin{array}{l}\text { Lustman PJ } \\
\text { et al. }(1997)^{48}\end{array}$ & $\begin{array}{l}\text { - The reduction in depression symptoms was significantly greater in depressed people } \\
\text { treated with nortriptyline compared with those receiving placebo }(-10.2 \mathrm{vs}-5.8, \mathrm{p}=.03) \text {. } \\
\text { - Nortriptyline was not statistically superior to placebo in reducing glycated hemoglobin } \\
\text { of the depressed subjects }(\mathrm{p}=.5) \text {. } \\
\text { - For people in the nortriptyline and placebo groups, the compliance with the medication } \\
\text { regimen and with blood glucose monitoring did not differ as a function of treatment } \\
\text { received during the 8-week trial. } \\
\text { - Path analysis indicated that the direct effect of nortriptyline was to worsen glycemic } \\
\text { control whereas depression improvement had an independent beneficial effect on } \\
\text { glycated hemoglobin. These findings were not explained by the relationships of } \\
\text { nortriptyline treatment to weight change }(\mathrm{r}=-0.21, \mathrm{p}=.31) \text { or depression improvement } \\
\text { to compliance with the protocol for self-monitoring of blood glucose }(\mathrm{r}=0.01, \mathrm{p}=.97) \text {. }\end{array}$ & $\begin{array}{l}\text { - The HbA1c level cannot appropriately be used to evaluate the } \\
\text { effects of treatment on glucose control during the study (8 weeks) } \\
\text { since this measurement reflects average blood glucose levels over } \\
\text { the preceding } 90-120 \text { days. }\end{array}$ \\
\hline $\begin{array}{l}\text { Lustman PJ } \\
\text { et al. }(1998)^{49}\end{array}$ & $\begin{array}{l}\text { - The percentage of people achieving remission of depression (Beck Depression } \\
\text { Inventory score } \leq 9 \text { ) was greater in the CBT group than in the control group: post- } \\
\text { treatment, } 85.0 \% \text { of people in the CBT group compared with } 27.3 \% \text { of controls } \\
\text { achieved remission (difference, } 57.7 \text { percentage points [95\% Cl, } 33 \text { to } 82 \text { percentage } \\
\text { points]) (P< } 0.001) \text {; at follow-up, } 70.0 \% \text { of people in the CBT group compared with } \\
\text { 33.3\% of controls achieved remission (difference, } 36.7 \text { percentage points [Cl, } 9 \text { to } 65 \\
\text { percentage points]) (P = 0.03). } \\
\text { - Post-treatment glycosylated hemoglobin levels were not different in the two groups, but } \\
\text { follow-up mean glycosylated hemoglobin levels were significantly better in the CBT } \\
\text { group than in the control group (9.5\% compared with } 10.9 \% \text {; }=0.03 \text { ). } \\
\text { - Covariate-adjusted mean GHb levels were lower in the nondepressed group at both the } \\
\text { post-treatment (8.5\% compared with } 10.9 \% \text {; }=0.003 \text { ) and follow- up ( } 9.2 \% \text { compared } \\
\text { with } 12.1 \% \text {; } \mathrm{P}=0.006) \text { evaluations compared to depressed group at the both time } \\
\text { points. } \\
\text { - Over the } 10 \text {-week treatment period, compliance with self-monitoring of blood glucose } \\
\text { levels declined in the CBT group compared with the control group (P = 0.01). }\end{array}$ & $\begin{array}{l}\text { - The explanation for decreased adherence to glucose monitoring in } \\
\text { CBT group may be that participation of the CBT group in diabetes } \\
\text { education complicated an already complex regimen and was more } \\
\text { than the people could handle. It is a well-established principle of } \\
\text { compliance that any action that complicates a treatment regimen } \\
\text { (such as adding a medication or using divided rather than single- } \\
\text { dose schedules) usually decreases compliance with other } \\
\text { components of treatment. }\end{array}$ \\
\hline $\begin{array}{l}\text { Williams } J W \\
\text { et al. }(2004)^{50}\end{array}$ & $\begin{array}{l}\text { - At } 12 \text { months, diabetic patients who were assigned to intervention had less severe } \\
\text { depression (range, } 0 \text { to } 4 \text { on a checklist of } 20 \text { depression items; between-group } \\
\text { difference, }-0.43 \text { [ } 95 \% \text { CI, }-0.57 \text { to }-0.29 \text { ]; } \mathrm{P}<0.001 \text { ) than did participants who } \\
\text { received usual care. } \\
\text { - In the intervention group, weekly exercise days increased (between-group difference, } \\
0.50 \text { day [CI, } 0.12 \text { to } 0.89 \text { day]; } \mathrm{P}=0.001 \text { ); other self-care behaviors were not affected. } \\
\text { - At baseline, mean }( \pm \mathrm{SD} \text { ) hemoglobin A1c levels were } 7.28 \% \pm 1.43 \% \text {; follow-up values } \\
\text { were unaffected by the intervention }(\mathrm{P}>0.2 \text { ). }\end{array}$ & $\begin{array}{l}\text { - In this study, subjects were significantly older, less likely to } \\
\text { receive hypoglycemic medications, and had much better mean } \\
\text { hemoglobin A1c levels at baseline than did subjects in other } \\
\text { studies. }\end{array}$ \\
\hline Lin EH et al. & - During the 12-month intervention period, enhanced depression care and outcomes were & - Perhaps 1) the seemingly logical assumption reflects too \\
\hline
\end{tabular}


Table 8: Major findings of studies investigating depression treatment in people with diabetes and depression (cont.)

\begin{tabular}{|c|c|c|}
\hline$(2006)^{46}$ & $\begin{array}{l}\text { not associated with improved diabetes self-care behaviors (healthy nutrition, physical } \\
\text { activity, or smoking cessation). } \\
\text { - Relative to the usual care group, the intervention group reported a higher rate of } \\
\text { nonadherence to oral hypoglycemic agents (mean difference }=-6.3 \%, 95 \% \mathrm{CI},-11.91 \% \\
\text { to }-0.71 \% \text { ). Adherence to lipid-lowering agents and to antihypertensive medicines was } \\
\text { similar for the } 2 \text { groups. }\end{array}$ & $\begin{array}{l}\text { simplistic an understanding of the relation between depression } \\
\text { and behavior changes or/and 2) the modest effects of the } \\
\text { intervention on depression outcomes may not have been powerful } \\
\text { enough to increase optimism and motivation, prerequisites for } \\
\text { good self-care. } \\
\text { - Intervention patients showed lower adherence to oral } \\
\text { hypoglycemic medicines may highlights the complexity and } \\
\text { challenge people face in managing multiple medical conditions on } \\
\text { a daily basis. }\end{array}$ \\
\hline
\end{tabular}




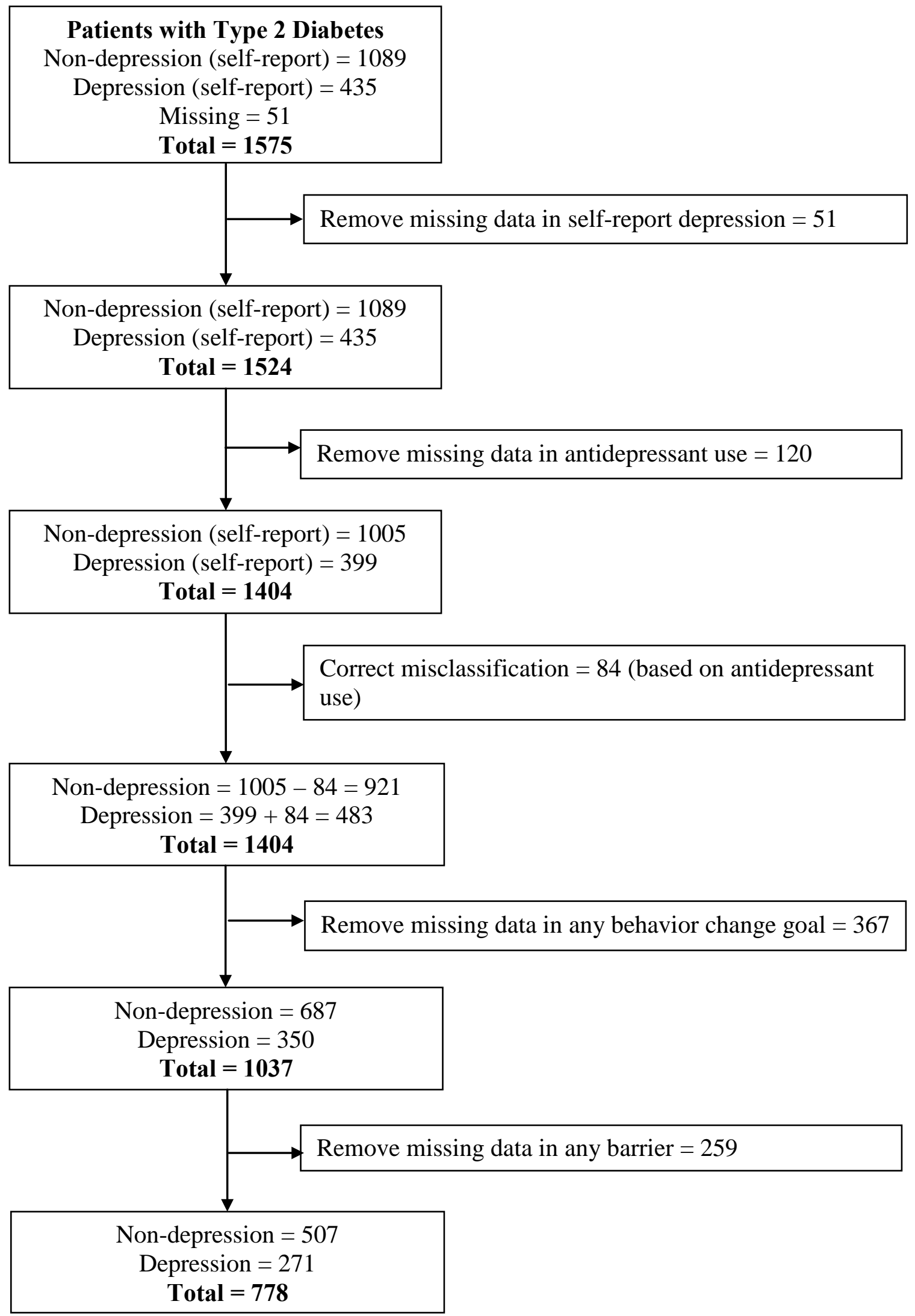

Figure 1: Flowchart of patients in this analysis 
Table 9: Demographic and clinical characteristics of patients with type 2 diabetes by depression/antidepressant status

\begin{tabular}{|c|c|c|c|c|c|c|}
\hline & $\begin{array}{l}\text { Non-depression } \\
\quad(\mathrm{n}=507)\end{array}$ & $\begin{array}{l}\text { Depression with } \\
\text { Antidepressant } \\
\quad(\mathrm{n}=181)\end{array}$ & $\begin{array}{c}\text { Depression } \\
\text { without } \\
\text { Antidepressant } \\
(\mathrm{n}=90) \\
\end{array}$ & $\begin{array}{l}\text { No. of } \\
\text { Missing } \\
\text { Value }\end{array}$ & $P$ value $^{\mathrm{a}}$ & $P$ value $^{\mathrm{b}}$ \\
\hline $\begin{array}{l}\text { Age, median (q1- } \\
\text { q3),y }\end{array}$ & $60(52-69)$ & $55(49-62)$ & $57(49-70)$ & $0,0,1$ & $<.0001$ & 0.04 \\
\hline $\begin{array}{l}\text { BMI, median (q1- } \\
\text { q3), kg/m² }\end{array}$ & $\begin{array}{c}33.16(28.78- \\
39.14) \\
\end{array}$ & $\begin{array}{c}34.75(30.90- \\
40.14) \\
\end{array}$ & $\begin{array}{c}33.03(28.37- \\
39.49) \\
\end{array}$ & $\begin{array}{c}46,30 \\
11\end{array}$ & 0.03 & 0.14 \\
\hline \multicolumn{7}{|l|}{ Gender, N (\%) } \\
\hline Men & $228(44.97)$ & $49(27.07)$ & $27(30.00)$ & \multirow{2}{*}{0} & \multirow{2}{*}{$<.0001$} & \multirow{2}{*}{0.61} \\
\hline Women & $279(55.03)$ & 132 (72.93) & $63(70.00)$ & & & \\
\hline \multicolumn{7}{|l|}{ Race, N (\%) } \\
\hline White & $437(86.71)$ & $155(85.64)$ & $76(86.36)$ & \multirow{3}{*}{$3,0,2$} & \multirow{3}{*}{0.79} & \multirow{3}{*}{0.96} \\
\hline Black & $41(8.13)$ & $14(7.73)$ & $7(7.95)$ & & & \\
\hline Others & $26(5.16)$ & $12(6.63)$ & $5(5.68)$ & & & \\
\hline \multicolumn{7}{|c|}{ Educational status, N (\%) } \\
\hline \begin{tabular}{l|l} 
Did not finish \\
high school
\end{tabular} & $59(11.68)$ & 21 (11.67) & $6(6.67)$ & \multirow{3}{*}{$2,1,0$} & \multirow{3}{*}{0.66} & \multirow{3}{*}{0.35} \\
\hline High school & $232(45.94)$ & $84(46.67)$ & 48 (53.33) & & & \\
\hline $\begin{array}{l}\text { Some college or } \\
\text { greater }\end{array}$ & $214(42.38)$ & 75 (41.67) & $36(40.00)$ & & & \\
\hline \multicolumn{7}{|l|}{ Smoking, N (\%) } \\
\hline Never & $324(76.78)$ & 109 (68.99) & $49(63.64)$ & \multirow{3}{*}{$\begin{array}{c}85,23 \\
13\end{array}$} & \multirow{3}{*}{0.01} & \multirow{3}{*}{0.64} \\
\hline Former & $21(4.98)$ & $7(4.43)$ & $3(3.90)$ & & & \\
\hline Current & $77(18.25)$ & $42(26.58)$ & $25(32.47)$ & & & \\
\hline $\begin{array}{l}\text { Alcohol drinking, } \mathrm{N} \\
\text { (\%) }\end{array}$ & $134(26.64)$ & 35 (19.34) & $20(22.47)$ & $4,0,1$ & 0.05 & 0.55 \\
\hline $\begin{array}{l}\text { Family history of } \\
\text { diabetes, N (\%) }\end{array}$ & 365 (72.71) & $140(78.65)$ & $67(74.44)$ & $5,3,0$ & 0.17 & 0.44 \\
\hline $\begin{array}{l}\text { Years with diabetes, } \\
\text { median (q1-q3) }\end{array}$ & $2(0-10)$ & $3(0-10)$ & $1(0-9)$ & $\begin{array}{c}91,36 \\
15\end{array}$ & 0.84 & 0.17 \\
\hline $\begin{array}{l}\text { Diabetes education, } \\
\mathrm{N}(\%)\end{array}$ & $120(23.81)$ & $53(29.44)$ & $13(14.44)$ & $3,1,0$ & 0.84 & 0.007 \\
\hline $\begin{array}{l}\text { HbA1c, median (q1- } \\
\text { q3),\% }\end{array}$ & 7.7 (6.7-9.3) & 7.7 (6.8-9.3) & $7.7(6.7-9.5)$ & $\begin{array}{l}168,51 \\
25\end{array}$ & 0.80 & 0.80 \\
\hline \multicolumn{7}{|l|}{ Complications, N (\%) } \\
\hline $\begin{array}{l}\text { High blood } \\
\text { pressure }\end{array}$ & $355(70.02)$ & $131(72.38)$ & $58(64.44)$ & 0 & 0.94 & 0.18 \\
\hline Stroke & $22(4.34)$ & $11(6.08)$ & $6(6.67)$ & 0 & 0.24 & 0.85 \\
\hline $\begin{array}{l}\text { Heart disease / } \\
\text { Chest pain }\end{array}$ & $140(27.61)$ & $50(27.62)$ & 30 (33.33) & 0 & 0.57 & 0.33 \\
\hline $\begin{array}{l}\text { Kidney / } \\
\text { Bladder } \\
\text { problems }\end{array}$ & 76 (14.99) & $43(23.76)$ & $18(20.00)$ & 0 & 0.009 & 0.49 \\
\hline
\end{tabular}


Table 9: Demographic and clinical characteristics of patients with type 2 diabetes by depression/antidepressant status (cont.)

\begin{tabular}{|c|c|c|c|c|c|c|}
\hline $\begin{array}{l}\text { Numbness / Pain } \\
\text { / Tingling of } \\
\text { hands/feet }\end{array}$ & $200(39.45)$ & 88 (48.62) & $50(55.56)$ & 0 & 0.002 & 0.28 \\
\hline $\begin{array}{l}\text { Eye or vision } \\
\text { problems }\end{array}$ & 155 (30.57) & 75 (41.44) & $45(50.00)$ & 0 & 0.0001 & 0.18 \\
\hline $\begin{array}{l}\text { Problems with } \\
\text { sexual function }\end{array}$ & 75 (14.79) & 31 (17.13) & 17 (18.89) & 0 & 0.29 & 0.72 \\
\hline $\begin{array}{l}\text { No. of } \\
\text { complications, } \\
\text { median (q1-q3) }\end{array}$ & $2(1-3)$ & $2(1-3)$ & $2(1-3)$ & 0 & 0.0002 & 0.58 \\
\hline $\begin{array}{l}\text { With any } \\
\text { complication, N (\%) }\end{array}$ & 468 (92.31) & $171(94.48)$ & $83(92.22)$ & 0 & 0.47 & 0.47 \\
\hline $\begin{array}{l}\text { With } \geq 3 \\
\text { complications, } N \\
(\%)\end{array}$ & $160(31.56)$ & 79 (43.65) & 44 (48.89) & 0 & 0.0001 & 0.41 \\
\hline Insulin, N (\%) & $128(25.25)$ & $58(32.04)$ & $22(24.44)$ & 0 & 0.20 & 0.20 \\
\hline \multicolumn{7}{|c|}{$\begin{array}{l}{ }^{a} \text { The } \mathrm{P} \text { value is used to make comparisons between patients with and without depression. For categorical } \\
\text { variables, the } \mathrm{P} \text { value is generated from the } \chi^{2} \text { test. For continuous variables, the } \mathrm{P} \text { value is generated from the } \\
\text { Wilcoxon rank sum test since all the variables are not normally distributed. } \\
\text { b The } \mathrm{P} \text { value is used to make comparisons between patients with and without antidepressant in the depressed } \\
\text { subgroup. For categorical variables, the } \mathrm{P} \text { value is generated from the } \chi^{2} \text { test. For continuous variables, the } \mathrm{P} \\
\text { value is generated from the Wilcoxon rank sum test since all the variables are not normally distributed. }\end{array}$} \\
\hline
\end{tabular}


Table 10: Self-identified behavior change goals of patients with type 2 diabetes by depression/antidepressant status

\begin{tabular}{|l|c|c|c|c|c|}
\hline & $\begin{array}{c}\text { Non- } \\
\text { depression } \\
(\mathrm{n}=507)\end{array}$ & $\begin{array}{c}\text { Depression } \\
\text { with } \\
\text { Antidepressant } \\
(\mathrm{n}=181)\end{array}$ & $\begin{array}{c}\text { Depression } \\
\text { without } \\
\text { Antidepressant } \\
(\mathrm{n}=90)\end{array}$ & P value $^{\mathrm{a}}$ & P value $^{\mathrm{b}}$ \\
\hline $\begin{array}{l}\text { No. of self-identified behavior } \\
\text { change goals, median (q1-q3) }\end{array}$ & $2(1-4)$ & $2(1-4)$ & $2(1-3)$ & 0.11 & 0.26 \\
\hline Activity, N (\%) & $265(52.27)$ & $111(61.33)$ & $48(53.33)$ & 0.09 & 0.21 \\
\hline Eating, N (\%) & $370(72.98)$ & $139(76.80)$ & $64(71.11)$ & 0.56 & 0.31 \\
\hline Medication taking, N (\%) & $90(17.75)$ & $34(18.78)$ & $20(22.22)$ & 0.46 & 0.50 \\
\hline Monitoring, N (\%) & $112(22.09)$ & $46(25.41)$ & $22(24.44)$ & 0.34 & 0.86 \\
\hline $\begin{array}{l}\text { Problem solving for blood sugars } \\
\text { and sick days, N (\%) }\end{array}$ & $81(15.98)$ & $42(23.20)$ & $17(18.89)$ & 0.05 & 0.42 \\
\hline $\begin{array}{l}\text { Reducing risks of diabetes } \\
\text { complications, N (\%) }\end{array}$ & $252(49.70)$ & $89(49.17)$ & $38(42.22)$ & 0.45 & 0.28 \\
\hline
\end{tabular}


Table 11: Barriers to diabetes self-care of patients with type 2 diabetes by depression/antidepressant status

\begin{tabular}{|c|c|c|c|c|c|}
\hline & $\begin{array}{c}\text { Non- } \\
\text { depression } \\
(n=507)\end{array}$ & $\begin{array}{c}\text { Depression } \\
\text { with } \\
\text { Antidepressant } \\
(\mathrm{n}=181)\end{array}$ & $\begin{array}{c}\text { Depression } \\
\text { without } \\
\text { Antidepressant } \\
(\mathrm{n}=90)\end{array}$ & $\mathrm{P}_{\text {value }}{ }^{\mathrm{a}}$ & P value ${ }^{b}$ \\
\hline No. of barriers, median (q1-q3) & $6(3-8)$ & $7(5-10)$ & $7(5-9)$ & $<.0001$ & 0.75 \\
\hline $\begin{array}{l}\text { I don't know what to do or how } \\
\text { to do it, } \mathrm{N}(\%)\end{array}$ & 405 (79.88) & $155(85.64)$ & $77(85.56)$ & 0.05 & 0.99 \\
\hline It's too hard, N (\%) & $330(65.09)$ & $134(74.03)$ & $70(77.78)$ & 0.004 & 0.50 \\
\hline I don't have the time, $\mathrm{N}(\%)$ & $282(55.62)$ & $101(55.80)$ & $52(57.78)$ & 0.82 & 0.76 \\
\hline My health is not good, N (\%) & $264(52.07)$ & $123(67.96)$ & $62(68.89)$ & $<.0001$ & 0.88 \\
\hline $\begin{array}{l}\text { I can't see well enough to do it, } \mathrm{N} \\
(\%)\end{array}$ & 99 (19.53) & $46(25.41)$ & $30(33.33)$ & 0.007 & 0.17 \\
\hline I can't afford it, N (\%) & $201(39.64)$ & $98(54.14)$ & $40(44.44)$ & 0.003 & 0.13 \\
\hline No place to do it, $\mathrm{N}(\%)$ & $132(26.04)$ & $57(31.49)$ & $23(25.56)$ & 0.30 & 0.31 \\
\hline $\begin{array}{l}\text { I don't have the will power, } \mathrm{N} \\
\text { (\%) }\end{array}$ & $317(62.52)$ & $142(78.45)$ & $63(70.00)$ & 0.0002 & 0.13 \\
\hline $\begin{array}{l}\text { My family / friends don't support } \\
\text { me, N (\%) }\end{array}$ & 153 (30.18) & 76 (41.99) & $30(33.33)$ & 0.01 & 0.17 \\
\hline I can't remember to do it, $\mathrm{N}(\%)$ & $190(37.48)$ & $88(48.62)$ & $39(43.33)$ & 0.01 & 0.41 \\
\hline It's too uncomfortable, N (\%) & $198(39.05)$ & $93(51.38)$ & $41(45.56)$ & 0.005 & 0.37 \\
\hline It's not that important, N (\%) & $117(23.08)$ & $48(26.52)$ & $26(28.89)$ & 0.19 & 0.68 \\
\hline I don't enjoy it, N (\%) & $299(58.97)$ & $114(62.98)$ & $60(66.67)$ & 0.15 & 0.55 \\
\hline \multicolumn{6}{|c|}{$\begin{array}{l}{ }^{\mathrm{a}} \text { The distributions between patients with and without depression are compared using the } \chi^{2} \text { tests for categorical } \\
\text { variables and the Wilcoxon rank sum test for continuous variables since the number of barriers is not normally } \\
\text { distributed. } \\
{ }^{b} \text { The distributions between patients with and without antidepressant in the depressed subgroup are compared } \\
\text { using the } \chi^{2} \text { tests for categorical variables and the Wilcoxon rank sum test for continuous variables since the } \\
\text { number of barriers is not normally distributed. }\end{array}$} \\
\hline
\end{tabular}


Table 12: Multivariable Models

\begin{tabular}{|c|c|c|c|}
\hline \multicolumn{3}{|c|}{ Model 1: Association between depression and the number of goals $(\mathrm{n}=769)$} & \multirow{2}{*}{$\begin{array}{r}\text { Adjusted R-Square }=0.0789 \\
95 \% \text { Confidence Interval }\end{array}$} \\
\hline Variables & $\begin{array}{l}\text { Coefficient } \\
\text { Estimate }\end{array}$ & $\mathrm{P}$ value & \\
\hline Depression (yes/no) & 0.10 & 0.47 & $(-0.16,0.35)$ \\
\hline Age (year) & -0.02 & $<.0001$ & $(-0.03,-0.01)$ \\
\hline \multicolumn{4}{|l|}{ Race (ref = White) } \\
\hline Black & -0.56 & 0.02 & $(-1.01,-0.10)$ \\
\hline Others & -0.68 & 0.01 & $(-1.22,-0.15)$ \\
\hline \multicolumn{4}{|c|}{$\begin{array}{l}\text { Educational status (ref }=\text { Some college or } \\
\text { greater) }\end{array}$} \\
\hline Did not finish high school & -0.88 & $<.0001$ & $(-1.30,-0.46)$ \\
\hline High school diploma & -0.51 & 0.0002 & $(-0.77,-0.25)$ \\
\hline No. of barriers $(7-13 / 0-6)$ & 0.28 & 0.03 & $(0.04,0.53)$ \\
\hline \multicolumn{3}{|c|}{ Model 2: Association between depression and the number of barriers $(n=683)$} & Adjusted R-Square $=0.1166$ \\
\hline Variables & $\begin{array}{l}\text { Coefficient } \\
\text { Estimate }\end{array}$ & P value & 95\% Confidence Interval \\
\hline Depression (yes/no) & 1.01 & 0.0001 & $(0.50,1.52)$ \\
\hline $\operatorname{BMI}\left(\mathrm{kg} / \mathrm{m}^{2}\right)$ & 3.40 & $<.0001$ & $(2.26,4.54)$ \\
\hline \multicolumn{4}{|l|}{ Race (ref = White) } \\
\hline Black & 0.92 & 0.05 & $(0.01,1.83)$ \\
\hline Others & 1.70 & 0.006 & $(0.50,2.90)$ \\
\hline \multicolumn{4}{|c|}{$\begin{array}{l}\text { Educational status (ref = Some college or } \\
\text { greater) }\end{array}$} \\
\hline Did not finish high school & 1.11 & 0.01 & $(0.27,1.95)$ \\
\hline High school diploma & 0.41 & 0.11 & $(-0.10,0.92)$ \\
\hline Age (year) & -0.009 & 0.38 & $(-0.03,0.01)$ \\
\hline Insulin (yes/no) & 1.10 & $<.0001$ & $(0.56,1.65)$ \\
\hline \multicolumn{3}{|c|}{$\begin{array}{l}\text { Model 3A: Association between antidepressant use and the number of goals in the } \\
\text { depressed subgroup }(\mathrm{n}=264)\end{array}$} & Adjusted R-Square $=0.0854$ \\
\hline Variables & $\begin{array}{l}\text { Coefficient } \\
\text { Estimate }\end{array}$ & P value & 95\% Confidence Interval \\
\hline Antidepressant (yes/no) & 0.31 & 0.18 & $(-0.15,0.77)$ \\
\hline Age (year) & -0.01 & 0.17 & $(-0.03,0.006)$ \\
\hline \multicolumn{4}{|l|}{ Race (ref = White) } \\
\hline Black & -0.82 & 0.04 & $(-1.62,-0.02)$ \\
\hline Others & -1.43 & 0.001 & $(-2.31,-0.56)$ \\
\hline \multicolumn{4}{|c|}{$\begin{array}{l}\text { Educational status (ref = Some college or } \\
\text { greater) }\end{array}$} \\
\hline Did not finish high school & -0.74 & 0.05 & $(-1.49,0.01)$ \\
\hline High school diploma & -0.36 & 0.13 & $(-0.82,0.10)$ \\
\hline Insulin (yes/no) & -0.43 & 0.07 & $(-0.91,0.04)$ \\
\hline Family history of diabetes (yes/ no) & 0.49 & 0.06 & $(-0.03,1.02)$ \\
\hline
\end{tabular}


Table 12: Multivariable Models (cont.)

\begin{tabular}{|c|c|c|c|}
\hline \multicolumn{3}{|c|}{$\begin{array}{l}\text { Model 3B: Association between antidepressant use and the number of goals in the } \\
\text { depressed subgroup }(n=268)\end{array}$} & \multirow{2}{*}{$\begin{array}{c}\text { Adjusted R-Square }=0.0539 \\
\text { 95\% Confidence Interval }\end{array}$} \\
\hline Variables & $\begin{array}{l}\text { Coefficient } \\
\text { Estimate }\end{array}$ & $\mathrm{P}$ value & \\
\hline Antidepressant (yes/no) & 0.22 & 0.35 & $(-0.24,0.68)$ \\
\hline Age (year) & -0.02 & 0.02 & $(-0.04,-0.004)$ \\
\hline \multicolumn{4}{|l|}{ Race (ref = White) } \\
\hline Black & -0.79 & 0.05 & $(-1.59,0.01)$ \\
\hline Others & -1.34 & 0.003 & $(-2.23,-0.46)$ \\
\hline \multicolumn{3}{|c|}{$\begin{array}{l}\text { Model 4: Association between antidepressant use and the number of barriers in the } \\
\text { depressed subgroup }(n=228)\end{array}$} & Adjusted R-Square $=0.0955$ \\
\hline Variables & $\begin{array}{l}\text { Coefficient } \\
\text { Estimate }\end{array}$ & $\mathrm{P}$ value & 95\% Confidence Interval \\
\hline Antidepressant (yes/no) & 0.005 & 0.99 & $(-0.85,0.86)$ \\
\hline Age (year) & 0.01 & 0.52 & $(-0.02,0.05)$ \\
\hline $\operatorname{BMI}\left(\mathrm{Kg} / \mathrm{m}^{2}\right)$ & 3.71 & 0.0003 & $(1.74,5.68)$ \\
\hline \multicolumn{4}{|c|}{$\begin{array}{l}\text { Educational status (ref = Some college or } \\
\text { greater) }\end{array}$} \\
\hline Did not finish high school & 1.53 & 0.04 & $(0.08,2.99)$ \\
\hline High school diploma & 0.52 & 0.24 & $(-0.34,1.38)$ \\
\hline Insulin (yes/no) & 1.38 & 0.004 & $(0.45,2.30)$ \\
\hline
\end{tabular}




\section{APPENDIX A: DEMOGRAPHIC AND CLINICAL CHARACTERISTICS OF PATIENTS IN STUDY AND OUT OF STUDY}

\begin{tabular}{|c|c|c|c|c|}
\hline & $\begin{array}{l}\text { Out of Study } \\
(\mathrm{n}=797)\end{array}$ & $\begin{array}{l}\text { In Study } \\
(\mathrm{n}=778)\end{array}$ & $\begin{array}{l}\text { No. of } \\
\text { Missing }\end{array}$ & $\begin{array}{c}\mathrm{P} \\
\text { value }^{\mathrm{a}}\end{array}$ \\
\hline Depression status, N (\%) & 212 (33.87) & $271(34.83)$ & 171,0 & 0.70 \\
\hline Age, median (q1-q3), y & $60(51-69)$ & $58(51-68)$ & 6,1 & 0.17 \\
\hline BMI, median (q1-q3), kg/m² & $\begin{array}{l}32.84(28.15- \\
38.20)\end{array}$ & $\begin{array}{l}33.67(29.32- \\
39.42)\end{array}$ & 164,87 & 0.02 \\
\hline \multicolumn{5}{|l|}{ Gender, N (\%) } \\
\hline Men & $343(43.04)$ & $304(39.07)$ & \multirow{2}{*}{0} & \multirow{2}{*}{0.11} \\
\hline Women & 454 (56.96) & $474(60.93)$ & & \\
\hline \multicolumn{5}{|l|}{ Race, N (\%) } \\
\hline White & 647 (81.69) & $668(86.42)$ & \multirow{3}{*}{5,5} & \multirow{3}{*}{0.03} \\
\hline Black & $78(9.85)$ & $62(8.02)$ & & \\
\hline Others & 67 (8.46) & $43(5.56)$ & & \\
\hline \multicolumn{5}{|l|}{ Educational status, N (\%) } \\
\hline $\begin{array}{l}\text { Did not finish high } \\
\text { school }\end{array}$ & 95 (12.55) & $86(11.10)$ & \multirow{3}{*}{40,3} & \multirow{3}{*}{0.18} \\
\hline High school & $379(50.07)$ & $364(46.97)$ & & \\
\hline $\begin{array}{l}\text { Some college or } \\
\text { greater }\end{array}$ & $283(37.38)$ & $325(41.94)$ & & \\
\hline \multicolumn{5}{|l|}{ Smoking, N (\%) } \\
\hline Never & $534(76.83)$ & $482(73.36)$ & \multirow{3}{*}{$\begin{array}{l}102, \\
121\end{array}$} & \multirow{3}{*}{0.32} \\
\hline Former & $31(4.46)$ & $31(4.72)$ & & \\
\hline Current & 130 (18.71) & $144(21.92)$ & & \\
\hline Alcohol drinking, $\mathrm{N}(\%)$ & $241(30.98)$ & $189(24.45)$ & 19,5 & 0.004 \\
\hline Family history of diabetes, N (\%) & 544 (69.74) & $572(74.29)$ & 17,8 & 0.05 \\
\hline Years with diabetes, median (q1-q3) & $1(0-8)$ & $2(0-10)$ & $\begin{array}{l}186, \\
142\end{array}$ & 0.01 \\
\hline Diabetes education, N (\%) & $166(21.15)$ & $186(24.03)$ & 12,4 & 0.17 \\
\hline HbA1c, median (q1-q3),\% & $7.5(6.6-9.5)$ & $7.7(6.7-9.4)$ & $\begin{array}{l}316, \\
244\end{array}$ & 0.32 \\
\hline
\end{tabular}




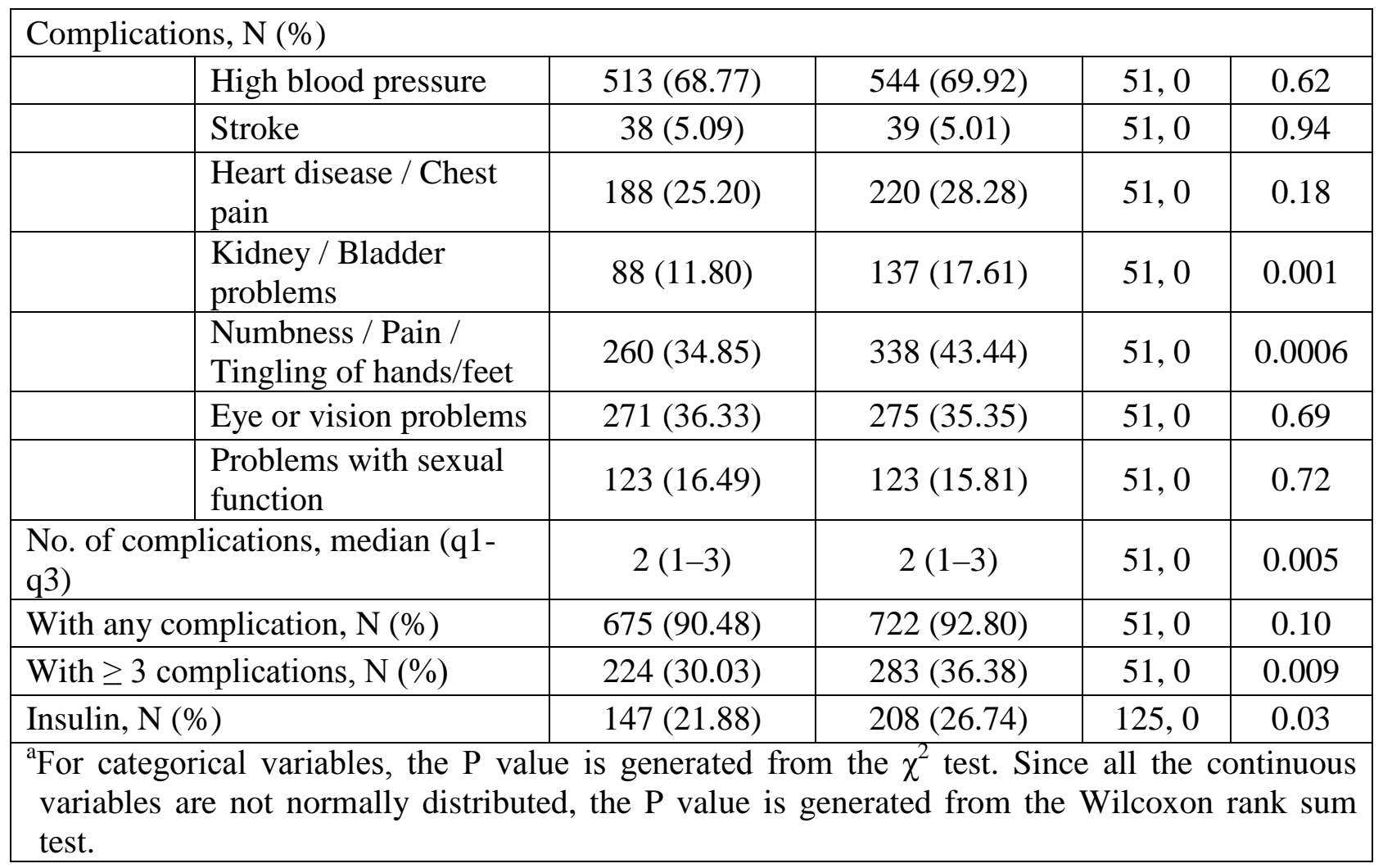




\section{APPENDIX B: ANTIDEPRESSANT}

\section{TCA (Tricyclic Antidepressant)}

Amitriptyline (Elavil)

Nortriptyline (Pamelor)

Imipramine (Tofranil)

Desipramine (Norpramin)

Clomipramine (Anafranil)

Protriptyline (Vivactil)

Lofepramine (Gamanil, Lomont)

Trimipramine (Surmontil)

Mianserin (Bolvidon)

Doxepin (Sinequan)

Amoxapine (Asendin)

Dosulepin (Prothiaden)

\section{SSRI (Selective Serotonin Reuptake Inhibitor)}

Fluoxetine (Prozac)

Paroxetine (Paxil)

Sertraline (Zoloft)

Fluvoxamine (Luvox)

Citalopram (Celexa)

Escitalopram (Lexapro)

SNERI (Serotonin/Norepinephrine Reuptake Inhibitor)

Reboxetine (Edronax)

Venlafaxine (Effexor)

Desvenlafaxine (Pristiq)

Duloxetine (Cymbalta)

Bupropion (Wellbutrin)

Nafazodone or Nafezodone or Nefazodone (Serzone)

Trazodone (Desyrel)

Maprotiline (Ludiomil)

Mirtazapine (Remeron)

MAO (Monoamine Oxidase Inhibitor)

Phenelzine (Nardil)

Meclobemide (moclobemide) (Aurorix, Manerix)

Selegiline (l-deprenyl)

Tranylcypromine (Parnate)

Isocarboxazid (Marplan)

\section{Miscellaneous}

St. John's wort

Flupentixol or flupenthixol (Depixol and Fluanxol)

Ademetionine (Gumbaral) 


\section{APPENDIX C: INSULIN}

\section{$\underline{\text { Rapid-acting insulins }}$}

Humalog (insulin lispro)

Novolog (insulin aspart)

Apidra (insulin glulisine)

Short-acting insulins

Humulin R (regular)

Novolin R (regular)

Intermediate-acting insulins

NPH

Humulin N

Novolin $\mathrm{N}$

\section{Lente}

Humulin L

\section{Long-acting insulins}

Humulin U (ultralente)

Lantus (insulin glargine)

\section{Pre-mixed insulin}

Pre-mixed insulin analogs

Humalog Mix 75/25 (insulin lispro)

Novolog Mix 70/30 (insulin aspart)

NPH-regular combinations

Humulin 70/30

Novolin 70/30

Humulin 50/50 


\section{BIBLIOGRAPHY}

1. National diabetes fact sheet: general information and national estimates on diabetes in the United States. In: U.S. Department of Health and Human Services CfDCaP, 2008, edAtlanta, GA2007.

2. Egede LE, Ellis C. The effects of depression on diabetes knowledge, diabetes selfmanagement, and perceived control in indigent patients with type 2 diabetes. Diabetes Technol Ther. Jun 2008;10(3):213-219.

3. National diabetes fact sheet: general information and national estimates on diabetes in the United States. In: U.S. Department of Health and Human Services CfDCaP, 2008, edAtlanta, GA2007.

4. Egede LE, Ellis C. The effects of depression on diabetes knowledge, diabetes selfmanagement, and perceived control in indigent patients with type 2 diabetes. Diabetes Technol Ther. Jun 2008;10(3):213-219.

5. Norris SL, Engelgau MM, Narayan KM. Effectiveness of self-management training in type 2 diabetes: a systematic review of randomized controlled trials. Diabetes Care. Mar 2001;24(3):561-587.

6. Morgan CL, Currie CJ, Peters JR. Relationship between diabetes and mortality - A population study using record linkage. Diabetes Care. Aug 2000;23(8):1103-1107.

7. Mclean MT, McElnay JC, Andrews WJ. The association of psychosocial and diabetes factors to diabetes knowledge. Int J Pharm Pract. 2001;9(Suppl):R9.

8. Weinger K, Butler HA, Welch GW, La Greca AM. Measuring diabetes self-care: a psychometric analysis of the Self-Care Inventory-Revised with adults. Diabetes Care. Jun 2005;28(6):1346-1352.

9. Peeples M, Mulcahy K, Tomky D, Weaver T. The conceptual framework of the National Diabetes Education Outcomes System (NDEOS). Diabetes Educ. Jul-Aug 2001;27(4):547562.

10. Anderson RM, Hiss RG, Stepien CJ, Fitzgerald JT, Funnell MM. The diabetes education experience of randomly selected patients under the care of community physicians. Diabetes Educ. Sep-Oct 1994;20(5):399-405. 
11. Siminerio LM, Funnell MM, Peyrot M, Rubin RR. US nurses' perceptions of their role in diabetes care: results of the cross-national Diabetes Attitudes Wishes and Needs (DAWN) study. Diabetes Educ. Jan-Feb 2007;33(1):152-162.

12. Peeples M, Tomky D, Mulcahy K, et al. Evolution of the American association of diabetes educators' diabetes education outcomes project. Diabetes Educator. Sep-Oct 2007;33(5):794817.

13. Skinner TC. Psychological barriers. Eur J Endocrinol. Oct 2004;151 Suppl 2:T13-17; discussion T29-30.

14. Glasgow RE, Nutting PA, Toobert DJ, et al. Effects of a brief computer-assisted diabetes self-management intervention on dietary, biological and quality-of-life outcomes. Chronic Illn. Mar 2006;2(1):27-38.

15. Morrow AS, Haidet P, Skinner J, Naik AD. Integrating diabetes self-management with the health goals of older adults: a qualitative exploration. Patient Educ Couns. Sep 2008;72(3):418-423.

16. Huang ES, Gorawara-Bhat R, Chin MH. Self-reported goals of older patients with type 2 diabetes mellitus. J Am Geriatr Soc. Feb 2005;53(2):306-311.

17. Estabrooks PA, Nelson CC, Xu S, et al. The frequency and behavioral outcomes of goal choices in the self-management of diabetes. Diabetes Educ. May-Jun 2005;31(3):391-400.

18. Schulman-Green DJ, Naik AD, Bradley EH, McCorkle R, Bogardus ST. Goal setting as a shared decision making strategy among clinicians and their older patients. Patient Educ Couns. Oct 2006;63(1-2):145-151.

19. Rachmani R, Slavacheski I, Berla M, Frommer-Shapira R, Ravid M. Treatment of high-risk patients with diabetes: motivation and teaching intervention: a randomized, prospective 8year follow-up study. J Am Soc Nephrol. Mar 2005;16 Suppl 1:S22-26.

20. Olivarius NF, Beck-Nielsen H, Andreasen AH, Horder M, Pedersen PA. Randomised controlled trial of structured personal care of type 2 diabetes mellitus. BMJ. Oct 27 2001;323(7319):970-975.

21. Sprague MA, Shultz JA, Branen LJ, Lambeth S, Hillers VN. Diabetes educators' perspectives on barriers for patients and educators in diabetes education. Diabetes Educ. Nov-Dec 1999;25(6):907-916.

22. Aljasem LI, Peyrot M, Wissow L, Rubin RR. The impact of barriers and self-efficacy on self-care behaviors in type 2 diabetes. Diabetes Educ. May-Jun 2001;27(3):393-404.

23. Clark M, Hampson SE. Implementing a psychological intervention to improve lifestyle selfmanagement in patients with type 2 diabetes. Patient Educ Couns. Mar 2001;42(3):247-256. 
24. Schoenberg NE, Drungle SC. Barriers to non-insulin dependent diabetes mellitus (NIDDM) self-care practices among older women. J Aging Health. Nov 2001;13(4):443-466.

25. Williamson AR, Hunt AE, Pope JF, Tolman NM. Recommendations of dietitians for overcoming barriers to dietary adherence in individuals with diabetes. Diabetes Educ. MarApr 2000;26(2):272-279.

26. Tu KS, Morrison E. Diabetes selfcare practices, barriers, and outcomes in an indigent population: an exploratory study. Journal of Nursing Science. 1996;1(88-98).

27. Vijan S, Stuart NS, Fitzgerald JT, et al. Barriers to following dietary recommendations in Type 2 diabetes. Diabet Med. Jan 2005;22(1):32-38.

28. Wagner J, Malchoff C, Abbott G. Invasiveness as a barrier to self-monitoring of blood glucose in diabetes. Diabetes Technol Ther. Aug 2005;7(4):612-619.

29. Nagelkerk J, Reick K, Meengs L. Perceived barriers and effective strategies to diabetes selfmanagement. J Adv Nurs. Apr 2006;54(2):151-158.

30. Daly JM, Hartz AJ, Xu Y, et al. An assessment of attitudes, behaviors, and outcomes of patients with type 2 diabetes. J Am Board Fam Med. May-Jun 2009;22(3):280-290.

31. Glasgow RE. Social-Environmental Factors in Diabetes: Barriers to Diabetes Self-care. Handbook of psychology and diabetes by Bradley C.: Harwood Academic, Berkshire, UK; 1994.

32. Knol MJ, Derijks HJ, Geerlings MI, et al. Influence of antidepressants on glycaemic control in patients with diabetes mellitus. Pharmacoepidemiol Drug Saf. Jun 2008;17(6):577-586.

33. Rubin RR, Ma Y, Marrero DG, et al. Elevated depression symptoms, antidepressant medicine use, and risk of developing diabetes during the diabetes prevention program. Diabetes Care. Mar 2008;31(3):420-426.

34. Rubin RR, Peyrot M. Psychological issues and treatments for people with diabetes. J Clin Psychol. Apr 2001;57(4):457-478.

35. Piette JD, Richardson C, Valenstein M. Addressing the needs of patients with multiple chronic illnesses: the case of diabetes and depression. Am J Manag Care. Feb 2004;10(2 Pt 2):152-162.

36. de Groot M, Anderson R, Freedland KE, Clouse RE, Lustman PJ. Association of depression and diabetes complications: a meta-analysis. Psychosom Med. Jul-Aug 2001;63(4):619-630.

37. Katon WJ, Rutter C, Simon G, et al. The association of comorbid depression with mortality in patients with type 2 diabetes. Diabetes Care. Nov 2005;28(11):2668-2672. 
38. Egede LE, Zheng D, Simpson K. Comorbid depression is associated with increased health care use and expenditures in individuals with diabetes. Diabetes Care. Mar 2002;25(3):464470.

39. Ciechanowski PS, Katon WJ, Russo JE. Depression and diabetes: impact of depressive symptoms on adherence, function, and costs. Arch Intern Med. Nov 27 2000;160(21):32783285.

40. Ciechanowski PS, Katon WJ, Russo JE, Hirsch IB. The relationship of depressive symptoms to symptom reporting, self-care and glucose control in diabetes. Gen Hosp Psychiatry. JulAug 2003;25(4):246-252.

41. Lin EH, Katon W, Von Korff M, et al. Relationship of depression and diabetes self-care, medication adherence, and preventive care. Diabetes Care. Sep 2004;27(9):2154-2160.

42. Park H, Hong Y, Lee H, Ha E, Sung Y. Individuals with type 2 diabetes and depressive symptoms exhibited lower adherence with self-care. J Clin Epidemiol. Sep 2004;57(9):978984.

43. Gonzalez JS, Safren SA, Cagliero E, et al. Depression, self-care, and medication adherence in type 2 diabetes: relationships across the full range of symptom severity. Diabetes Care. Sep 2007;30(9):2222-2227.

44. Kalsekar ID, Madhavan SS, Amonkar MM, et al. Depression in patients with type 2 diabetes: impact on adherence to oral hypoglycemic agents. Ann Pharmacother. Apr 2006;40(4):605611.

45. Kilbourne AM, Reynolds CF, 3rd, Good CB, Sereika SM, Justice AC, Fine MJ. How does depression influence diabetes medication adherence in older patients? Am J Geriatr Psychiatry. Mar 2005;13(3):202-210.

46. McKellar JD, Humphreys K, Piette JD. Depression increases diabetes symptoms by complicating patients' self-care adherence. Diabetes Educ. May-Jun 2004;30(3):485-492.

47. Katon WJ, Von Korff M, Lin EH, et al. The Pathways Study: a randomized trial of collaborative care in patients with diabetes and depression. Arch Gen Psychiatry. Oct 2004;61(10):1042-1049.

48. Lin EH, Katon W, Rutter C, et al. Effects of enhanced depression treatment on diabetes selfcare. Ann Fam Med. Jan-Feb 2006;4(1):46-53.

49. Lustman PJ, Freedland KE, Griffith LS, Clouse RE. Fluoxetine for depression in diabetes: a randomized double-blind placebo-controlled trial. Diabetes Care. May 2000;23(5):618-623.

50. Lustman PJ, Griffith LS, Clouse RE, et al. Effects of nortriptyline on depression and glycemic control in diabetes: results of a double-blind, placebo-controlled trial. Psychosom Med. May-Jun 1997;59(3):241-250. 
51. Lustman PJ, Griffith LS, Freedland KE, Kissel SS, Clouse RE. Cognitive behavior therapy for depression in type 2 diabetes mellitus. A randomized, controlled trial. Ann Intern Med. Oct 15 1998;129(8):613-621.

52. Williams JW, Jr., Katon W, Lin EH, et al. The effectiveness of depression care management on diabetes-related outcomes in older patients. Ann Intern Med. Jun 15 2004;140(12):10151024.

53. Rush WA, Whitebird RR, Rush MR, Solberg LI, O'Connor PJ. Depression in patients with diabetes: does it impact clinical goals? J Am Board Fam Med. Sep-Oct 2008;21(5):392-397.

54. Zgibor JC, Peyrot M, Ruppert K, et al. Using the American Association of Diabetes Educators Outcomes System to identify patient behavior change goals and diabetes educator responses. Diabetes Educator. Sep-Oct 2007;33(5):839-842.

55. Fisher EB, Brownson CA, O'Toole ML, Shetty G, Anwuri VV, Glasgow RE. Ecological approaches to self-management: the case of diabetes. Am J Public Health. Sep 2005;95(9):1523-1535.

56. Sigurdardottir AK. Self-care in diabetes: model of factors affecting self-care. J Clin Nurs. Mar 2005;14(3):301-314.

57. Ismail K, Thomas SM, Maissi E, et al. Motivational enhancement therapy with and without cognitive behavior therapy to treat type 1 diabetes: a randomized trial. Ann Intern Med. Nov 18 2008;149(10):708-719. 